\title{
Thermodynamic modeling of ruminal fermentations
}

\author{
Anne OFFNER, Daniel SAUVANT* \\ Physiologie de la Nutrition et Alimentation, Institut National de la Recherche Agronomique, \\ 16 rue Claude Bernard, 75231 Paris Cedex 05, France
}

(Received 31 January 2005 - Accepted 28 March 2006)

\begin{abstract}
The main weakness of current rumen models is their inability to explain the endproducts of fermentation (volatile fatty acids, gas, and microbial matter) in a satisfactory way. The objective of this study was to improve this prediction based on the application of thermodynamic laws to microbial metabolism. Therefore, a dynamic model of rumen fermentation was developed. In this original approach, the reactions evolved with a decrease in Gibbs energy according to thermodynamic laws. Some simulated results obtained with this model were similar to experimental observations. The predicted post-prandial evolution of the volatile fatty acid profile was satisfactory. However, simulations of some other parameters $(\mathrm{pH}$, redox potential) were less reliable and further studies should be conducted to represent these better. The results allowed some properties resulting from thermodynamic principles to be identified and strengthened the importance of this subject.
\end{abstract}

\section{model / rumen / thermodynamic laws}

Résumé - Modélisation thermodynamique des fermentations ruminales. La principale limite des modèles du rumen actuellement développés est leur incapacité à prédire de façon satisfaisante les produits terminaux des fermentations (acides gras volatils, gaz et biomasse microbienne). Cette étude visait à améliorer cette prédiction en se basant sur l'application des lois de la thermodynamique au métabolisme microbien. Un modèle dynamique des fermentations ruminales a ainsi été développé. Dans cette approche originale, les réactions évoluent selon les lois de la thermodynamique, avec une diminution de l'énergie de Gibbs. Certains résultats des simulations, obtenues avec le modèle, concordent bien avec des observations expérimentales. Ainsi, l'évolution post-prandiale du profil des acides gras volatils était satisfaisante. Cependant, les simulations obtenues pour d'autres paramètres ( $\mathrm{pH}$, potentiel d'oxydo-réduction) ont été moins pertinentes et d'autres études doivent être menées pour mieux représenter ces facteurs. Les résultats ont permis d'identifier des propriétés résultant des principes de la thermodynamique et de souligner la pertinence et l'intérêt de cette démarche.

modèle / rumen / lois thermodynamiques

\footnotetext{
* Corresponding author: sauvant@inapg.inra.fr
} 


\section{NOMENCLATURE}

$\begin{array}{lll}\text { Symbol } & \text { Name } & \text { Unit } \\ {[\mathrm{x}]} & \text { concentration of species } \mathrm{x} & \mathrm{mol} \cdot \mathrm{L}^{-1} \\ \mathrm{E} & \text { oxidation-reduction potential } & \mathrm{V} \\ \mathrm{F} & \text { Faraday constant }\left(96485.31 \mathrm{C} \cdot \mathrm{mol}^{-1}\right) & \mathrm{C} \cdot \mathrm{mol}^{-1} \\ \mathrm{G} & \text { extensive Gibbs energy of a system } & \mathrm{kJ} \\ \Delta_{\mathrm{r}} \mathrm{G} & \text { reaction Gibbs energy for specified concentrations of species at specified } \mathrm{T}, \mathrm{P} \mathrm{kJ} \cdot \mathrm{mol}^{-1} \\ \Delta_{\mathrm{f}} \mathrm{G}(\mathrm{x}) & \text { Gibbs energy of formation of species } \mathrm{x} \text { at specified } \mathrm{T}, \mathrm{P} & \mathrm{kJ} \cdot \mathrm{mol}^{-1} \\ \mathrm{H} & \text { extensive enthalpy of a system } & \mathrm{kJ} \\ \Delta_{\mathrm{f}} \mathrm{H}^{\mathrm{o}}(\mathrm{x}) & \text { standard enthalpy of formation of species x at specified } \mathrm{T}, \mathrm{P} & \mathrm{kJ} \cdot \mathrm{mol}^{-1} \\ \mathrm{k}_{1}, \mathrm{k}_{2} & \text { rate constant of the forward and reverse reaction } & \mathrm{variable} \\ \mathrm{K}_{\mathrm{eq}} & \text { equilibrium constant for a specified reaction at specified } \mathrm{T}, \mathrm{P} & \mathrm{dimensionless} \\ \mathrm{n} & \text { number of electrons involved in a cell reaction } & \mathrm{dimensionless} \\ \mathrm{P} & \text { pressure } & \mathrm{atm} \\ \mathrm{pH} & -\log \left[\mathrm{H}^{+}\right] & \mathrm{pH} \mathrm{unit} \\ \mathrm{R} & \text { gas constant }\left(8.31451 \mathrm{~J} \cdot \mathrm{K}^{-1} \cdot \mathrm{mol}^{-1}\right) & \mathrm{J} \cdot \mathrm{K}^{-1} \cdot \mathrm{mol}^{-1} \\ \mathrm{r}(\mathrm{t}) & \text { rate of the reaction } & \mathrm{mol} \cdot \mathrm{L}^{-1} \cdot \mathrm{min}^{-1} \\ \mathrm{~T} & \text { temperature } & \mathrm{K}\end{array}$

\section{INTRODUCTION}

During recent decades, farm animal models and feed evaluation systems have been developed in most industrialized countries. The role of the rumen in the nutritional response of the ruminant to its diet is essential. Models of whole rumen function have been proposed $[2,9,19,32]$ although these do not contain a mechanistic means to predict the variation of carbon (C) partitioning among microbes, gas and volatile fatty acids (VFA) [33]. The validation of the prediction of VFA profiles pointed out that simulations have not been entirely satisfactory $[3,11,28]$. Regarding the importance of these products [10], the current study intends to focus on this aspect. It was hypothesized that the failure of currently published models to predict $\mathrm{C}$ partitioning is due to their lack of explicit representation of thermodynamic principles.

Thermodynamic principles could be applied to determine which process can occur, in which direction and how strong the tendency is for the changes to take place. It is based on the principle that substances tend to react to achieve the lowest energy state. Kinetic laws rather describe the rates of the reactions. For a given bacterial species, the metabolic pathways and flows are mainly determined by the enzymatic environment, which is the outcome of the cell's genetic material. Therefore, in a monoculture, the kinetic laws are more important than thermodynamic ones. In contrast, in the case of a highly diversified microflora, like in the rumen, numerous metabolic pathways are a priori possible. So, it can be assumed that successful species and metabolic pathways are those which optimize the thermodynamic yield. Consequently, in the rumen, thermodynamic laws could play a more important driving role than kinetic laws. Some global thermodynamic approaches of microbial ecosystems have already been developed. These are mainly based on the use of macrochemical equations expressing system inputs and outputs and take into account the principles of Gibbs energy [14,38]. Kohn and Boston [17] developed a dynamic model of glucose fermentation based on thermodynamic limits. However, the thermodynamic efficiencies 
were considered static at steady state. To progress in this area, a simple thermodynamic driven model of ruminal fermentations was developed with the objective to predict variation in $\mathrm{C}$ flow partitioning among VFA, fermentation gas and microbial biomass.

\section{MATERIALS AND METHODS}

\subsection{Application of thermodynamic principles in mathematical modeling}

Thermodynamic principles state that spontaneous processes have a negative Gibbs energy change $\left(\Delta_{\mathrm{r}} \mathrm{G}<0\right)$. In this situation, the system releases energy to its surroundings as the process occurs. This principle was the current working assumption and the magnitude of the Gibbs energy change was assumed to be one of the driving forces of biochemical reactions occurring in the rumen. Thermodynamic principles applied to biochemical reactions were integrated in the model. Let us consider a reversible reaction: $\mathrm{aA}+\mathrm{bB} \frac{\frac{k_{1}}{k_{2}}}{\mathrm{c} C}+$ $\mathrm{dD}$, where the symbols A and B stand for the reactants of the reaction and the symbols $\mathrm{C}$ and $\mathrm{D}$ stand for the products of the reaction. The rate constant $k_{1}$ is for the forward reaction, $\mathrm{k}_{2}$ is that of the reverse reaction. In writing biochemical equations, the correct stoichiometric coefficients (a, b, c, d) should be used to balance atoms (e.g., C, $\mathrm{H}, \mathrm{O}$ ) and charges if necessary. The overall rate $(r)$ of the reaction can then be defined by:

$$
\begin{aligned}
r(t) & =\frac{-1}{a} \times \frac{d[A]}{d t}=\frac{-1}{b} \times \frac{d[B]}{d t} \\
& =\frac{1}{c} \times \frac{d[C]}{d t}=\frac{1}{d} \times \frac{d[D]}{d t} .
\end{aligned}
$$

Thus, biochemical reactions can be modeled with differential equations, describing the change in concentration of the various chemical species over time. The rate can also be written:

$$
\mathrm{r}(\mathrm{t})=\mathrm{k}_{1}[\mathrm{~A}]^{\mathrm{a}}[\mathrm{B}]^{\mathrm{b}}-\mathrm{k}_{2}[\mathrm{C}]^{\mathrm{c}}[\mathrm{D}]^{\mathrm{d}} .
$$

Equations (I) and (II) were the basic concepts for the construction of the current dynamic model of biochemical reactions.

Thermodynamic principles help to determine the rate constants for forward $\left(\mathrm{k}_{1}\right)$ and reverse $\left(\mathrm{k}_{2}\right)$ reactions. The change in Gibbs energy $\left(\Delta_{\mathrm{r}} \mathrm{G}, \mathrm{kJ} \cdot \mathrm{mol}^{-1}\right)$ of the reaction is given by:

$$
\begin{array}{r}
\Delta_{\mathrm{r}} \mathrm{G}=\Delta_{\mathrm{r}} \mathrm{G}^{\circ}+\mathrm{RTLn}(\mathrm{K}) \\
\text { with } \mathrm{K}=\frac{[\mathrm{C}]^{\mathrm{c}} \times[\mathrm{D}]^{\mathrm{d}}}{[\mathrm{A}]^{\mathrm{a}} \times[\mathrm{B}]^{\mathrm{b}}}
\end{array}
$$

$\Delta_{\mathrm{r}} \mathrm{G}^{\circ}$ represents the standard Gibbs energy change $(\mathrm{T}=298 \mathrm{~K},[\mathrm{x}]=1)$, $\mathrm{R}$ the gas constant, $\mathrm{T}$ the temperature in $\mathrm{K},[\mathrm{x}]$ the activities of reactants and products expressed as a concentration in $\mathrm{mol} \cdot \mathrm{L}^{-1}$ or as atmospheric pressure.

The thermodynamic laws may help to predict if a reaction would happen, whenever the Gibbs energy change is negative, the process is spontaneous. In a closed system, the Gibbs energy decreases to $\Delta_{\mathrm{r}} \mathrm{G}=$ 0 , which corresponds to a dynamic equilibrium. When this thermodynamic equilibrium is reached, the equilibrium constant of the reaction $\left(\mathrm{K}_{\mathrm{eq}}\right)$ can be specified from equations (II) and (III).

equation (II): $\mathrm{r}(\mathrm{t})=0 \rightarrow \mathrm{K}_{\mathrm{eq}}=\frac{\mathrm{k}_{1}}{\mathrm{k}_{2}}$

equation (III): $\Delta_{\mathrm{r}} \mathrm{G}=0 \rightarrow \mathrm{K}_{\mathrm{eq}}=\mathrm{e}^{\frac{-\Delta_{\mathrm{r}} \mathrm{G}^{0}}{\mathrm{RT}}}(\mathrm{V})$

$\mathrm{K}_{\mathrm{eq}}$ is determined with the standard Gibbs energy change $\left(\Delta_{\mathrm{r}} \mathrm{G}^{\circ}\right)$ values, which can be calculated from tabulated thermodynamic data. Thus, in the model, the dynamic differential equations were written for each molecule involved in a reaction as below for $\mathrm{A}$ :

$\frac{\mathrm{d}[\mathrm{A}]}{\mathrm{dt}}=-\mathrm{ak}_{1}[\mathrm{~A}]^{\mathrm{a}}[\mathrm{B}]^{\mathrm{b}}+\mathrm{a} \frac{\mathrm{k}_{1}}{\mathrm{~K}_{\mathrm{eq}}}[\mathrm{C}]^{\mathrm{c}}[\mathrm{D}]^{\mathrm{d}}$.

These principles can be applied for oxidation-reduction reactions with electron 


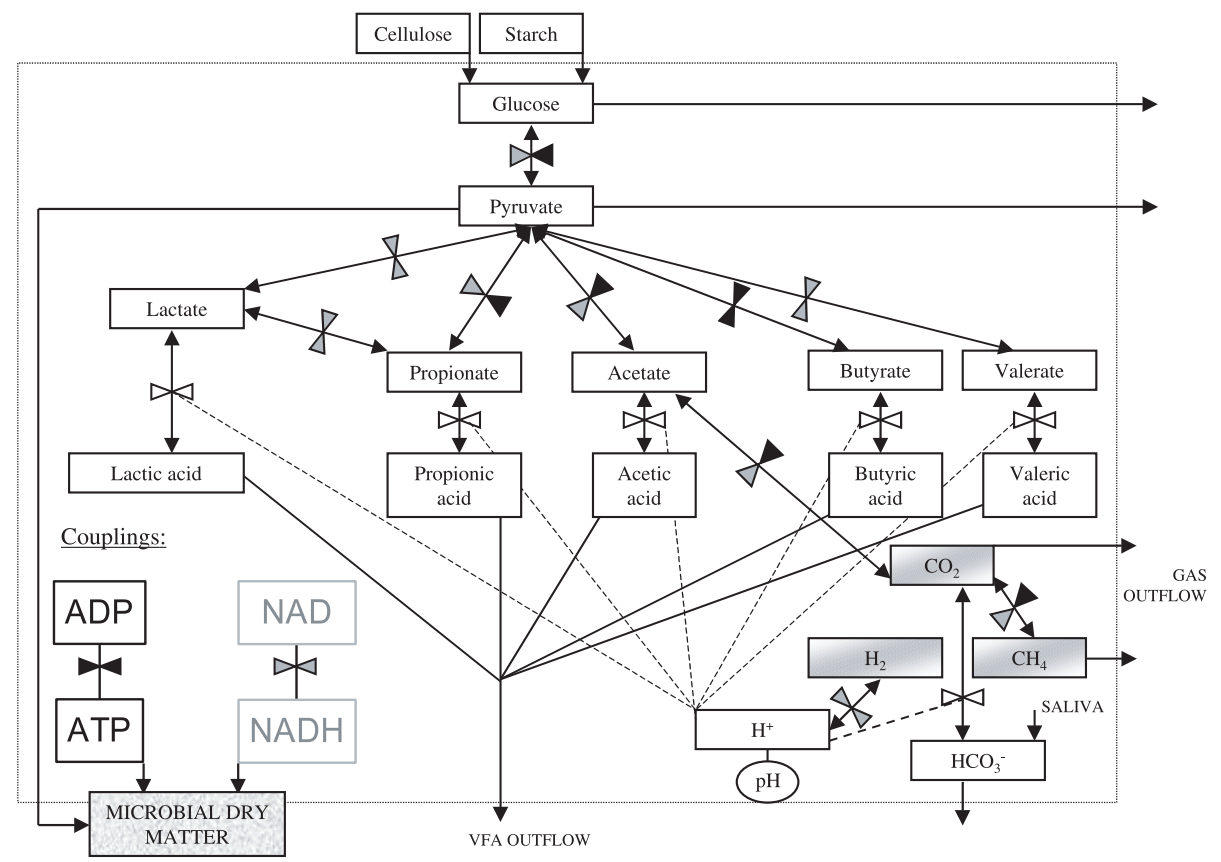

Figure 1. Simplified Forrester diagram to model fermentation pathways in the rumen.

$\left(\mathrm{e}^{-}\right)$and proton $\left(\mathrm{H}^{+}\right)$exchanges, which are common in the rumen: a $\mathrm{Ox}+\mathrm{ne}^{-}+$ $\mathrm{cH}^{+} \leftrightarrow \mathrm{b}$ Red, Red and Ox are respectively the reducing and the oxidizing agents, $\mathrm{n}$ is the number of electrons transferred in the half-reaction. The Nernst equation is also used to calculate the redox potential $(\mathrm{E}$, volt) of the reaction:

$$
\begin{array}{r}
\mathrm{E}=\mathrm{E}^{\circ}+\frac{\mathrm{RT}}{\mathrm{nF}} \operatorname{Ln} \frac{[\mathrm{Ox}]^{\mathrm{a}}\left[\mathrm{H}^{+}\right]^{\mathrm{c}}}{[\mathrm{Red}]^{\mathrm{b}}} \quad(\mathrm{VII}) \\
\mathrm{E}=\mathrm{E}_{\mathrm{pH}}^{\prime \circ}+\frac{\mathrm{RT}}{\mathrm{nF}} \operatorname{Ln} \frac{[\mathrm{Ox}]^{\mathrm{a}}}{[\mathrm{Red}]^{\mathrm{b}}}
\end{array}
$$

with $\mathrm{E}_{\mathrm{pH}}^{\circ}=\mathrm{E}^{\circ}+\mathrm{c} \times \frac{\mathrm{RT}}{\mathrm{nF}} \times \operatorname{Ln}(10) \times \mathrm{pH}$

where $\mathrm{E}^{\circ}$ is the standard redox potential of the half-reaction ( $\mathrm{T}=298 \mathrm{~K}, \mathrm{pH}=0)$, $\mathrm{E}^{\circ}{ }_{\mathrm{pH}}$ is the standard redox potential for a given $\mathrm{pH}, \mathrm{F}$ is the Faraday constant.

Two half-reactions should be coupled to achieve the electron balance. The electrons are then transferred from the reduction couple $\left(E_{\text {red }}\right)$ to the oxidation couple
$\left(E_{\text {ox }}\right)$. The variation of Gibbs energy $\left(\Delta_{\mathrm{r}} \mathrm{G}\right)$ is proportional to the redox potential of variation $(\triangle \mathrm{E})$ for the cell reaction:

$\Delta_{\mathrm{r}} \mathrm{G}=-\mathrm{nF}\left(\mathrm{E}_{\mathrm{ox}}-\mathrm{E}_{\mathrm{red}}\right)=-\mathrm{nF} \Delta \mathrm{E} . \quad(\mathrm{VIII})$

\subsection{Model development}

The model of ruminal fermentations was based on 23 compartments corresponding to the major biochemical molecules and another compartment representing microbial dry matter. The compartments are expressed in $\mathrm{mol} \cdot \mathrm{L}^{-1}$ for solutions, in atm for gas and in $\mathrm{g} \cdot \mathrm{L}^{-1}$ for microbial dry matter. Each of these is defined by a dynamic differential equation representing the difference between inflows and outflows in the compartment. The reactions are considered to be reversible and thermodynamic laws presented previously (IV) were used in the model. The Forrester diagram of the model 
is summarized in Figure 1. The equations, variables and parameters are listed in the annex. The model was developed using the Dynamo language [31]. The Euler integration method was used for the numerical integration of the 24 dynamic differential equations with a step time of $0.1 \mathrm{~min}$. The simulation time was 4 days in order to reach a dynamic equilibrium. A simulation of day 4 is presented in the results. Feeding occurred at the beginning of each day.

\subsubsection{Model compartments}

\subsubsection{Soluble carbohydrates}

The system simulated a daily "bolus" intake of cellulose and degradable starch, main carbohydrates ingested by the animal, of respectively 50 and 25 glucoseequivalent moles. Offner et al. [29] compared different rumen models on their way of predicting starch digestion. Both cellulose and starch were degraded into glucose, with assumed fractional rates of 0.08 and $0.3 \% \cdot \mathrm{min}^{-1}$ respectively. Glucose was then converted to pyruvate by glycolysis, which is summarized by one reaction:

$\mathrm{C}_{6} \mathrm{H}_{12} \mathrm{O}_{6}+2\left(\mathrm{ADP}+\mathrm{Pi}^{2-}\right)+2 \mathrm{NAD}^{+} \leftrightarrow$ $2 \mathrm{C}_{3} \mathrm{H}_{3} \mathrm{O}_{3}^{-}+2 \mathrm{ATP}+2\left(\mathrm{NADH}+\mathrm{H}^{+}\right)+$ $2 \mathrm{H}_{2} \mathrm{O}$.

The pyruvate formed was converted to volatile fatty acids. Two pathways can lead to the formation of propionate. Pyruvate can be reduced to propionate by the lactate pathway $(2,3)$ or by the succinate pathway (4):

$\mathrm{C}_{3} \mathrm{H}_{3} \mathrm{O}_{3}{ }^{-}+\mathrm{NADH}+\mathrm{H}^{+} \leftrightarrow \mathrm{C}_{3} \mathrm{H}_{5} \mathrm{O}_{3}^{-}+$ $\mathrm{NAD}^{+}$

$\mathrm{C}_{3} \mathrm{H}_{5} \mathrm{O}_{3}{ }^{-}+\mathrm{NADH}+\mathrm{H}^{+} \leftrightarrow \mathrm{C}_{3} \mathrm{H}_{5} \mathrm{O}_{2}^{-}+$ $\mathrm{H}_{2} \mathrm{O}+\mathrm{NAD}^{+}$

$\mathrm{C}_{3} \mathrm{H}_{3} \mathrm{O}_{3}{ }^{-}+2 \mathrm{NADH}+3 \mathrm{H}^{+}+\mathrm{ADP}+\mathrm{Pi}^{2-}$ $\leftrightarrow \mathrm{C}_{3} \mathrm{H}_{5} \mathrm{O}_{2}{ }^{-}+2 \mathrm{H}_{2} \mathrm{O}+2 \mathrm{NAD}^{+}+$ATP. (4)

The succinate pathway (4) was assumed to produce 1 ATP although there is no confirmation of this value. Pyruvate can also be oxidized into acetylCoA, which is a precursor for acetate and butyrate. Reactions for acetate $\left(\mathrm{C}_{2}\right)$ and butyrate $\left(\mathrm{C}_{4}\right)$ formation are the following:

$\begin{array}{ll}\mathrm{C}_{3} \mathrm{H}_{3} \mathrm{O}_{3}{ }^{-}+\left(\mathrm{ADP}+\mathrm{Pi}^{2-}\right)+\mathrm{NAD} & \stackrel{\leftrightarrow}{+} \\ \mathrm{C}_{2} \mathrm{H}_{3} \mathrm{O}_{2}{ }^{-}+\mathrm{CO}_{2}+\mathrm{ATP}+\mathrm{NADH} & (5) \\ 2 \mathrm{C}_{3} \mathrm{H}_{3} \mathrm{O}_{3}^{-}+\left(\mathrm{ADP}+\mathrm{Pi}^{2-}\right)+2 \mathrm{H}^{+} & \leftrightarrow \\ \mathrm{C}_{4} \mathrm{H}_{7} \mathrm{O}_{2}{ }^{-}+2 \mathrm{CO}_{2}+\mathrm{ATP}+\mathrm{H}_{2} \mathrm{O} . & (6)\end{array}$

Pyruvate can also lead to the formation of minor VFA in $\mathrm{C}_{5}$ or $\mathrm{C}_{6}$, like valerate:

$2 \mathrm{C}_{3} \mathrm{H}_{3} \mathrm{O}_{3}{ }^{-}+3 \mathrm{NADH}+4 \mathrm{H}^{+} \leftrightarrow \mathrm{C}_{5} \mathrm{H}_{9} \mathrm{O}_{2}^{-}$

$+\mathrm{CO}_{2}+2 \mathrm{H}_{2} \mathrm{O}+3 \mathrm{NAD}^{+}$.

VFA leave the system with a fractional outflow rate of $0.5 \% \cdot \mathrm{min}^{-1}$ corresponding approximately to their transit and absorption from the rumen.

\subsubsection{Gas}

Carbon dioxide is formed during reactions (5), (6) and (7). NAD ${ }^{+}$can be regenerated by methanogenesis or acetogenesis from $\mathrm{CO}_{2}$. The two reactions are assumed to be associated with the formation of 1 and $0.25 \mathrm{~mol}$ of ATP respectively.

$\mathrm{CO}_{2}+4 \mathrm{NADH}+4 \mathrm{H}^{+}+$

$\left(\mathrm{ADP}+\mathrm{Pi}^{2-}\right) \leftrightarrow \mathrm{CH}_{4}+3 \mathrm{H}_{2} \mathrm{O}$

$+4 \mathrm{NAD}^{+}+\mathrm{ATP}$

$2 \mathrm{CO}_{2}+4 \mathrm{NADH}+3 \mathrm{H}^{+}+$

$0.25\left(\mathrm{ADP}+\mathrm{Pi}^{2-}\right) \leftrightarrow \mathrm{C}_{2} \mathrm{H}_{3} \mathrm{O}_{2}{ }^{-}+2.25 \mathrm{H}_{2} \mathrm{O}$

$+4 \mathrm{NAD}^{+}+0.25 \mathrm{ATP}$.

The dynamics of $\mathrm{H}$ production and utilization was modeled with $\mathrm{NAD}^{+} / \mathrm{NADH}$ as the main electron acceptor and donor. The model does not consider other electron acceptors and donors even though others are known to exist. By convention, $\mathrm{NAD}^{+} / \mathrm{NADH}$ were chosen to represent the electron acceptor and donor. Hydrogen can be formed from $\mathrm{H}^{+}$by an oxidationreduction reaction:

$\mathrm{H}^{+}+\mathrm{NADH} \leftrightarrow \mathrm{H}_{2}+\mathrm{NAD}^{+}$.

$\mathrm{CO}_{2}, \mathrm{CH}_{4}$ and $\mathrm{H}_{2}$ activities were expressed in atm. When gas pressure in the rumen 
was above $1 \mathrm{~atm}$, gas was assumed to escape the rumen relative to the gas proportions [17]. The relation was then similar to a mass action law.

\subsubsection{Regulatory components}

Protons $\left(\mathrm{H}^{+}\right)$are involved in several reactions:

- formation of carbon dioxide from bicarbonate ions $\mathrm{HCO}_{3}^{-}$coming from saliva (inflow of $0.01 \mathrm{~mol} \cdot \mathrm{L}^{-1} \cdot \mathrm{min}^{-1}$ ):

$\mathrm{HCO}_{3}{ }^{-}+\mathrm{H}^{+} \leftrightarrow \mathrm{H}_{2} \mathrm{CO}_{3} \leftrightarrow \mathrm{CO}_{2}+\mathrm{H}_{2} \mathrm{O}$.

- formation of hydrogen by oxidationreduction according to reaction (10),

- equilibrium between formed anions and corresponding acids:

$\mathrm{A}^{-}+\mathrm{H}^{+} \leftrightarrow \mathrm{AH}$.

The $\mathrm{pH}$ had an influence on all the reactions where it is involved in the determination of equilibrium constants.

All oxidation-reduction reactions (1-5 and 7-10) can be considered to be indirectly coupled with $\mathrm{NAD}^{+} / \mathrm{NADH}$. In a closed system, the dynamic equilibrium is reached when $\Delta \mathrm{G}=\Delta \mathrm{E}=0$. An open system is never at equilibrium, $\Delta \mathrm{E} \neq 0$, therefore the convergence of the redox potentials of the different reactions over time is a priori not possible to obtain. However, the average redox potential of the rumen $\left(E_{\text {mean }}\right)$ was defined by the weighed average of the redox potentials of each couple $\left(\mathrm{E}_{\mathrm{i}}\right)$. The weighting coefficients were proportional to the amount of the oxidized and reduced forms of each oxidation-reduction couple. For a given oxidation-reduction couple, reaction flows have been considered as an exponential function of the difference between $E_{\text {mean }}$ and $E_{i}$. This principle was previously applied in modeling [20]. The objective was to favor the convergence of the redox potentials to an average value.
Finally, ATP is produced by fermentation processes $(1,4,5,6,8,9)$ and is used for maintenance and growth of microbes.

\subsubsection{Microbial population}

The amount of microbial dry matter in the rumen is regulated by flows related to growth, lysis and transit. The flows for growth and lysis are expressed as functions of the amount of microbial dry matter and basal growth rate of microorganisms. The rates for growth and lysis are also largely dependent on the ATP/ADP ratio. Growth is defined as a positive exponential function of $\mathrm{x}$, where $\mathrm{x}=\mathrm{k} \times\left(\frac{\mathrm{ATP}}{\mathrm{ADP}}-1\right)$. This expression allowed favoring growth when energy status was positive. In contrast, lysis is defined as a negative exponential function of $\mathrm{x}$. The flow for transit simply follows a mass action law. ATP and NADH are required for microbial growth and maintenance; this utilization depends on the amount of microbial dry matter. Carbon needed for microbial growth is assumed to come from pyruvate. The outflow of pyruvate changes with the apparent microbial growth. Microbial DM is supposed to contain $25 \%$ carbon [14].

\subsubsection{Model parameters - equilibrium constants}

The equilibrium constant of each reaction was calculated from the thermodynamic values of all molecules involved. Table I gives the standard thermodynamic properties as they are found in thermodynamic tables and provides the standard formation properties for the standard state, which is the state in a hypothetical ideal solution with all activities set to 1 . The standard enthalpy of formation $\left(\Delta_{\mathrm{f}} \mathrm{H}^{\circ}\right)$ does not depend on temperature, contrary to the standard Gibbs energy $\left(\Delta_{\mathrm{f}} \mathrm{G}^{\circ}\right)$. The Van't Hoff equation linked the two parameters to calculate values of $\Delta_{\mathrm{f}} \mathrm{G}^{\circ}$ for different temperatures (Tab. I). 
Table I. Thermodynamic properties for compounds of ruminal metabolism: standard Gibbs energy and enthalpy of formation. $\Delta_{\mathrm{f}} \mathrm{G}^{\circ}$ and $\Delta_{\mathrm{f}} \mathrm{H}^{\circ}$ expressed in $\mathrm{kJ} \cdot \mathrm{mol}^{-1}, \mathrm{pH}=0$.

\begin{tabular}{llccc}
\hline & & $\begin{array}{c}\Delta_{\mathrm{f}} \mathrm{G}^{\circ} \\
\text { at } 298 \mathrm{~K}\end{array}$ & \multicolumn{1}{c}{$\Delta_{\mathrm{f}} \mathrm{H}^{\circ}$} & $\begin{array}{c}\Delta_{\mathrm{f}} \mathrm{G}^{\circ} \\
\text { at } 311 \mathrm{~K}^{a}\end{array}$ \\
\hline Glucose & {$[17,25,37]$} & -916.97 & -1263.78 & -901.84 \\
Pyruvate & {$[18,25]$} & -474.50 & -596.60 & -469.17 \\
Lactate & {$[17,25,37]$} & -516.72 & -686.64 & -509.31 \\
Propionate & {$[25,36]$} & -360.00 & -511.08 & -353.41 \\
Acetate & {$[17,18,37]$} & -369.60 & -485.60 & -364.54 \\
Butyrate & {$[17,37]$} & -372.04 & -535.55 & -364.91 \\
Valerate & {$[36]$} & -368.40 & -556.80 & -360.18 \\
$\mathrm{HCO}_{3}{ }^{-}(\mathrm{aq})$ & {$[25,37]$} & -587.10 & -692.29 & -582.51 \\
$\mathrm{H}_{2} \mathrm{O}(\mathrm{L})$ & {$[17,25,37]$} & -237.19 & -285.84 & -235.07 \\
$\mathrm{CO}_{2}(\mathrm{~g})$ & {$[18,37]$} & -394.50 & -393.60 & -394.54 \\
$\mathrm{CH}_{4}(\mathrm{~g})$ & {$[17,37]$} & -50.79 & -74.85 & -49.74 \\
$\mathrm{H}_{2}(\mathrm{~g})$ & {$[17,25,37]$} & 0 & 0 & 0 \\
$\mathrm{H}^{+}$ & {$[17,25,37]$} & 0 & 0 & 0 \\
$\mathrm{ADP}^{3-}$ & {$[1]$} & -1711.55 & -2005.24 & -1698.74 \\
$\mathrm{ATP}^{4-}$ & {$[1]$} & -2573.49 & -2997.91 & -2554.98 \\
$\mathrm{Pi}^{2-}$ & {$[25]$} & -1094.10 & -1294.00 & -1085.38 \\
$\mathrm{NAD}^{-}$ & {$[1]$} & 0 & 0 & 0 \\
$\mathrm{NADH}^{2-}$ & {$[1]$} & 22.65 & -31.94 & 25.03 \\
\hline
\end{tabular}

${ }^{a}$ Values at rumen temperature $\mathrm{T}=311 \mathrm{~K}$ were calculated using the Van't Hoff equation: $\Delta_{\mathrm{f}} G^{\circ}\left(T_{2}\right)=\frac{T_{2}}{T_{1}}\left(\Delta_{f} G^{\circ}\left(T_{1}\right)-\frac{T_{2}-T_{1}}{T_{2}} \times \Delta_{f} H^{\circ}\right)$.

Knowing the standard Gibbs energy of formation for each compound, the standard change in Gibbs energy of a reaction was calculated with the following formula: $\Delta_{\mathrm{r}} \mathrm{G}^{\circ}=\Sigma \Delta_{\mathrm{f}} \mathrm{G}^{\circ}$ products $-\Sigma \Delta_{\mathrm{f}} \mathrm{G}^{\circ}$ reactants. Table II presents the change in standard Gibbs energy for key reactions in the rumen. Equilibrium constants $\left(\mathrm{K}_{\mathrm{eq}}\right)$ could then be determined with equation (V). The rate constants for the reverse reaction were defined arbitrarily for the reactions, so that flows were realistic. Unfortunately, no direct measurements of reverse rates were available.

Numerous fermentation processes are oxidation-reduction processes. Each oxidation-reduction couple can be characterized by its redox potential. Table III presents the redox potentials of the halfreactions of the main oxidation-reduction equilibria occurring in the rumen. The redox potential in the rumen is around
$-0.35 \mathrm{~V}$. This thermodynamic condition does not favor pyruvate, lactate or $\mathrm{H}_{2}$ accumulation.

For the reactions of acid dissociation $(12-16)$, the equilibrium constants are defined by $\mathrm{K}_{\mathrm{a}}=10^{-\mathrm{pK}_{\mathrm{a}}}=\frac{\left[\mathrm{A}^{-}\right]\left[\mathrm{H}^{+}\right]}{[\mathrm{AH}]}$. The values of $\mathrm{pKa}$ for weak acids correspond to the $\mathrm{pH}$ at which the acid is half dissociated: lactic acid 3.86, acetic acid 4.75, butyric acid 4.82, valeric acid 4.84 and propionic acid 4.87. These values indicate that for usual conditions of rumen $\mathrm{pH}(6<\mathrm{pH}<$ $6.5)$, VFA are largely present under the dissociated form.

\section{RESULTS}

\subsection{Thermodynamic validation}

Simulated changes in Gibbs energy of the reactions $\left(\Delta_{\mathrm{r}} \mathrm{G}\right)$ varied from 0 
Table II. Change in standard Gibbs energy for key reactions in the rumen, expressed in $\mathrm{kJ} \cdot \mathrm{mol}^{-1}$ for various conditions of $\mathrm{pH}$ and temperature.

\begin{tabular}{lcccc}
\hline & $\Delta_{\mathrm{r}} \mathrm{G}^{\circ}$ at $298 \mathrm{~K}$ & $\Delta_{\mathrm{r}} \mathrm{G}^{\circ}$ at $311 \mathrm{~K}$ & $\Delta_{\mathrm{r}} \mathrm{G}^{\circ}(\mathrm{pH})$ & $\Delta_{\mathrm{r}} \mathrm{G}^{\circ}(\mathrm{pH}=7)$ at $311 \mathrm{~K}$ \\
\hline NAD $<>$ NADH & 22.65 & 25.03 & $\Delta_{\mathrm{r}} \mathrm{G}^{\circ}+\mathrm{RTLn}(10) \times \mathrm{pH}$ & $\mathbf{6 6 . 7}$ \\
ADP $<>$ ATP & -5.03 & -5.93 & $\Delta_{\mathrm{r}} \mathrm{G}^{\circ}+\mathrm{RTLn}(10) \times \mathrm{pH}$ & $\mathbf{3 5 . 7}$ \\
(1) $\mathbf{G l u}<>$ Pyr & 1.7 & 3.2 & $\Delta_{\mathrm{r}} \mathrm{G}^{\circ}-2 \mathrm{RTLn}(10) \times \mathrm{pH}$ & $\mathbf{- 8 0 . 2}$ \\
(2) $\mathbf{P y r}<>$ Lac & -65.2 & -64.9 & $\Delta_{\mathrm{r}} \mathrm{G}^{\circ}+\mathrm{RTLn}(10) \times \mathrm{pH}$ & $\mathbf{- 2 3 . 2}$ \\
(3) $\mathbf{L a c}<>$ Pro & -104.2 & -103.1 & $\Delta_{\mathrm{r}} \mathrm{G}^{\circ}+\mathrm{RTLn}(10) \times \mathrm{pH}$ & $\mathbf{- 6 1 . 4}$ \\
(4) $\mathbf{P y r}<>$ Pro & -173.0 & -175.3 & $\Delta_{\mathrm{r}} \mathrm{G}^{\circ}+3 \mathrm{RTLn}(10) \times \mathrm{pH}$ & $\mathbf{- 5 0 . 3}$ \\
(5) $\mathbf{P y r}<>$ Ace & -35.7 & -37.8 & $\Delta_{\mathrm{r}} \mathrm{G}^{\circ}$ & $\mathbf{- 3 7 . 8}$ \\
(6) $\mathbf{P y r}<>$ But & -221.6 & -217.1 & $\Delta_{\mathrm{r}} \mathrm{G}^{\circ}+2 \mathrm{RTLn}(10) \times \mathrm{pH}$ & $\mathbf{- 1 3 3 . 7}$ \\
(7) $\mathbf{P y r}<>$ Val & -356.6 & -361.6 & $\Delta_{\mathrm{r}} \mathrm{G}^{\circ}+4 \mathrm{RTLn}(10) \times \mathrm{pH}$ & $\mathbf{- 1 9 4 . 8}$ \\
(8) $\mathbf{C O}_{2}<>$ CH & -226.3 & -231.4 & $\Delta_{\mathrm{r}} \mathrm{G}^{\circ}+5 \mathrm{RTLn}(10) \times \mathrm{pH}$ & $\mathbf{- 2 3 . 0}$ \\
(9) $\mathbf{C O}_{2}<>$ Ace & -146.8 & -147.2 & $\Delta_{\mathrm{r}} \mathrm{G}^{\circ}+3.25 \mathrm{RTLn}(10) \times \mathrm{pH}$ & $\mathbf{- 2 2 . 2}$ \\
(10) $\mathbf{H}^{+}<>\mathbf{H}_{2}$ & -25.0 & -22.6 & $\Delta_{\mathrm{r}} \mathrm{G}^{\circ}+\mathrm{RTLn}(10) \times \mathrm{pH}$ & $\mathbf{1 9 . 1}$ \\
(11) $\mathbf{H C O}_{3}^{-}<>\mathbf{C O}_{2}$ & -47.1 & -44.5 & $\Delta_{\mathrm{r}} \mathrm{G}^{\circ}+\mathrm{RTLn}(10) \times \mathrm{pH}$ & $\mathbf{- 2 . 8}$ \\
\hline
\end{tabular}

Table III. Redox potentials at $\mathrm{pH}=0$ and at $\mathrm{pH}=7$ and $\mathrm{T}=311 \mathrm{~K}$.

\begin{tabular}{|c|c|c|c|c|}
\hline & & $\mathrm{E}^{\circ}$ (volt) & $\mathrm{E}^{\prime \circ}$ (volt) & $\frac{[\mathrm{Ox}]^{\mathrm{a}}}{[\operatorname{Red}]^{\mathrm{b}}}$ for $\mathrm{E}=-0.35 \mathrm{~V}$ \\
\hline (7) & 2 Pyruvate $^{-}+7 \mathrm{H}^{+}+6 \mathrm{e}^{-} \leftrightarrow$ Valerate $^{-}+\mathrm{CO}_{2}+2 \mathrm{H}_{2} \mathrm{O}$ & 0.495 & -0.009 & $6.98 \times 10^{-34}$ \\
\hline (3) & Lactate $^{-}+2 \mathrm{H}^{+}+2 \mathrm{e}^{-} \leftrightarrow$ Propionate $^{-}+\mathrm{H}_{2} \mathrm{O}$ & 0.410 & -0.022 & $2.34 \times 10^{-11}$ \\
\hline (4) & Pyruvate $^{-}+4 \mathrm{H}^{+}+4 \mathrm{e}^{-} \leftrightarrow$ Propionate $^{-}+\mathrm{H}_{2} \mathrm{O}$ & 0.309 & -0.123 & $1.93 \times 10^{-15}$ \\
\hline (2) & Pyruvate $^{-}+2 \mathrm{H}^{+}+2 \mathrm{e}^{-} \leftrightarrow$ Lactate $^{-}$ & 0.208 & -0.224 & $8.25 \times 10^{-5}$ \\
\hline (8) & $\mathrm{CO}_{2}+8 \mathrm{H}^{+}+8 \mathrm{e}^{-} \leftrightarrow \mathbf{C H}_{4}+2 \mathrm{H}_{2} \mathrm{O}$ & 0.161 & -0.271 & $5.73 \times 10^{-11}$ \\
\hline \multirow[t]{2}{*}{ (9) } & $2 \mathrm{CO}_{2}+7 \mathrm{H}^{+}+8 \mathrm{e}^{-} \leftrightarrow$ Acetate $^{-}+2 \mathrm{H}_{2} \mathrm{O}$ & 0.059 & -0.319 & $9.57 \times 10^{-5}$ \\
\hline & $\mathbf{N A D}^{+}+\mathrm{H}^{+}+2 \mathrm{e}^{-} \leftrightarrow \mathbf{N A D H}$ & -0.130 & -0.346 & $7.42 \times 10^{-1}$ \\
\hline (10) & $2 \mathbf{H}^{+}+2 \mathrm{e}^{-} \leftrightarrow \mathrm{H}_{2}$ & 0 & -0.432 & $4.55 \times 10^{2}$ \\
\hline (5) & Acetate $^{-}+\mathrm{CO}_{2}+2 \mathrm{H}^{+}+2 \mathrm{e}^{-} \leftrightarrow$ Pyruvate $^{-}+\mathrm{H}_{2} \mathrm{O}$ & -0.284 & -0.716 & $7.28 \times 10^{11}$ \\
\hline (1) & 2Pyruvate $^{-}+6 \mathrm{H}^{+}+4 \mathrm{e}^{-} \leftrightarrow$ Glucose & -0.095 & -0.743 & $2.98 \times 10^{25}$ \\
\hline
\end{tabular}

to $-100 \mathrm{~kJ} \cdot \mathrm{mol}^{-1}$ (Fig. 2). The negative values demonstrate that the reactions proceed in the spontaneous thermodynamic direction.

The system can either maximize the production of highly energetic molecules or minimize entropy (S) production depending on the energetic situation. There is a clear relationship between Gibbs energy and entropy production $(\mathrm{G}=\mathrm{H}-\mathrm{TS})$. In case of energetic deficiency, the system tends to minimize the loss of Gibbs energy and so increase entropy. The system then favors the production of acetate. Sauvant et al. [34] reported that in this case, ATP and NADH production per carbon of VFA is greater. In contrast, in the most favorable situations, there is an adaptation to the energy and molecular hydrogen excess brought by the feeds; the system favors the production of longer chain VFA (propionate and minor VFA), leading to more molecular formation. Therefore, this situation is associated with lower entropy due to higher order (less molecules formed).

\subsection{Study of glucose fermentation and VFA profile}

The simulations of glucose fermentation showed, for thermodynamic reasons, that 


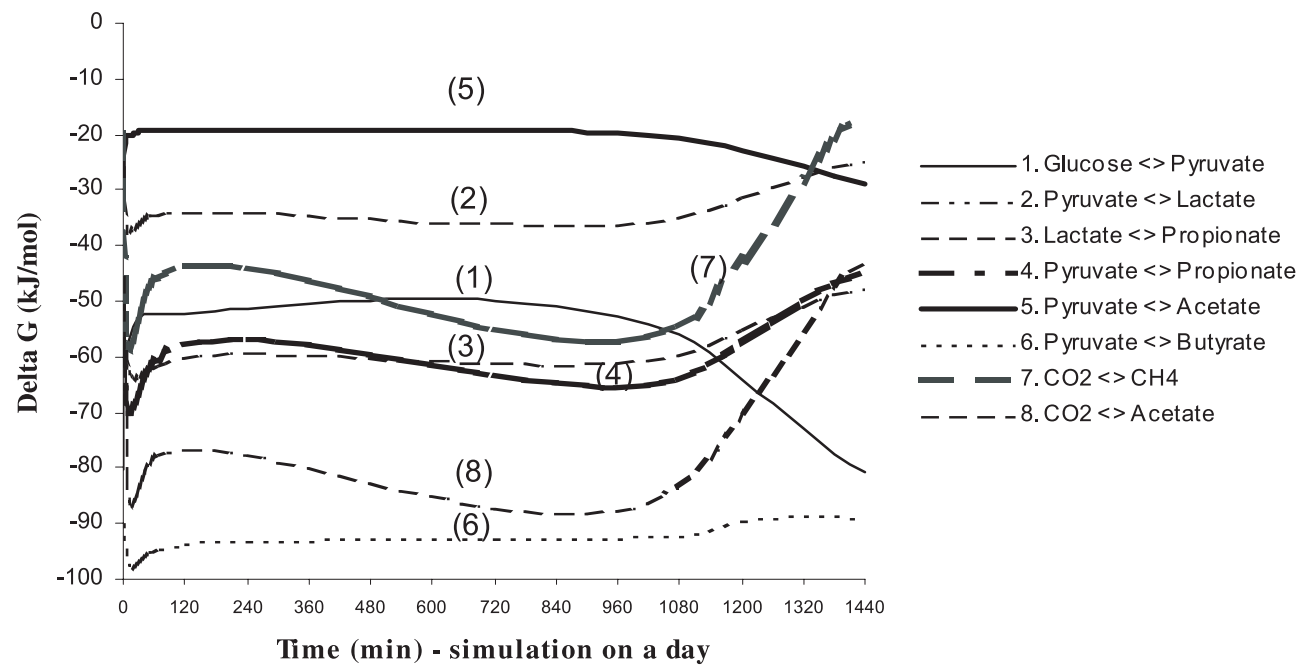

Figure 2. Change in Gibbs energy $\left(\Delta_{\mathrm{r}} \mathrm{G}\right)$ for various key reactions in the rumen.

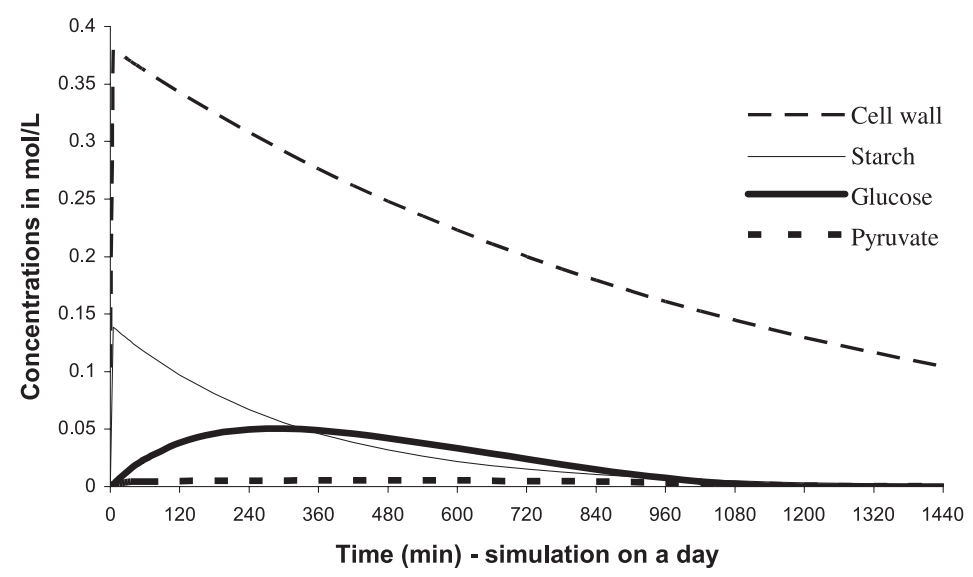

Figure 3. Degradation kinetics of cell wall and starch in the rumen.

glucose offered a rather strong resistance to microbial fermentation (Fig. 3). This was consistent with the presence of significant amounts of soluble carbohydrate observed in the rumen [21] or in vitro [4]. This could partly be explained by the low concentrations of ADP and NAD in the rumen. These two molecules are absolutely necessary for glycolysis.

Regarding the fluxes and partitions of VFA, the model reflected fairly well the dynamics and stoichiometry of the rumen (Fig. 4). Feeding was followed by an increase of propionate at the expense of acetate and butyrate. A post-prandial increase of the propionate to acetate and butyrate ratio is usually observed. However, this phenomenon was exacerbated compared to experimental observations. The acetate to propionate ratio $(\mathrm{A} / \mathrm{P})$ ranged normally between 2 and 5. Simulated values of A/P could reach an unrealistic value of 15 


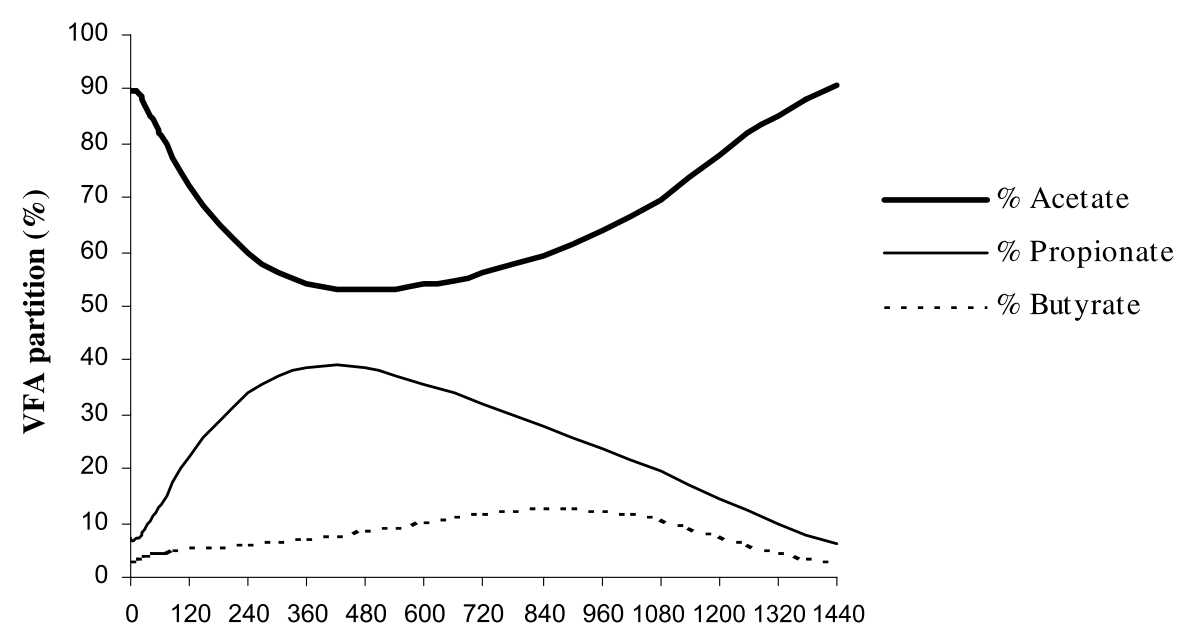

Time (min) - simulation on a day

Figure 4. Evolution of acetate, propionate and butyrate proportions.

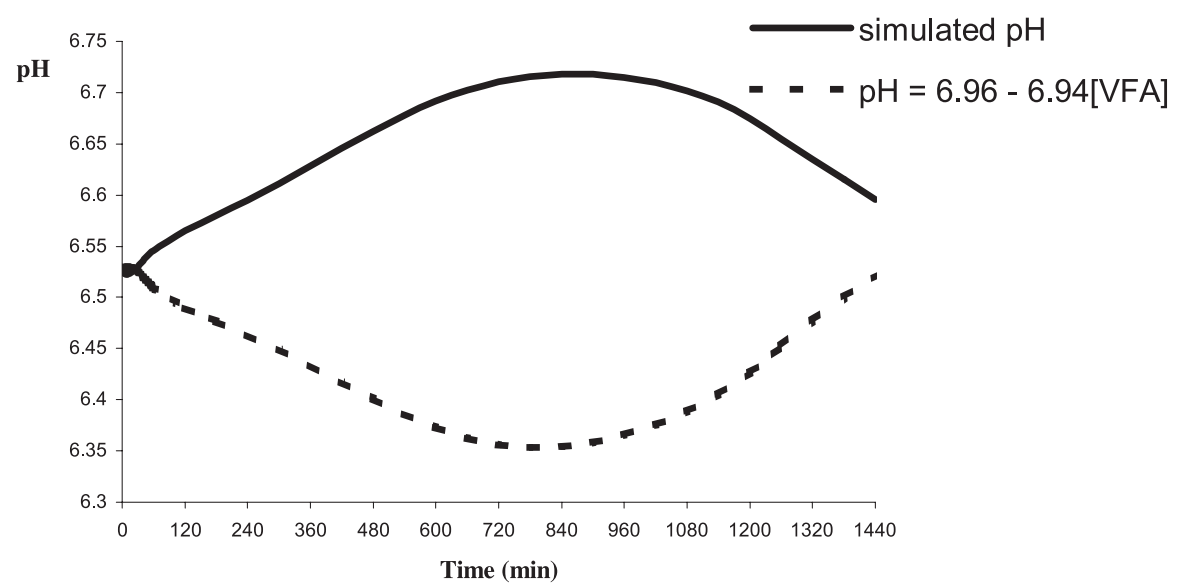

Figure 5. Comparison between simulated $\mathrm{pH}$ and empirical $\mathrm{pH}$ determination from VFA concentration in the rumen.

during transient periods, especially before feeding. The A/P ratio was influenced by various factors, which are more or less linked to energy availability of the substrates. A literature review on starch digestion in the rumen indicated that the $\mathrm{A} / \mathrm{P}$ ratio decreases with increasing amounts of starch digestible in the rumen [27].

\subsection{Study of regulatory parameters}

Predicted values for $\mathrm{pH}$ were fairly realistic, ranging from 6.4 to 6.7 ; however, the prediction of $\mathrm{pH}$ changes during the day was not satisfactory because it was opposite to experimental observations (Fig. 5). Indeed, after feeding, the increase in VFA 


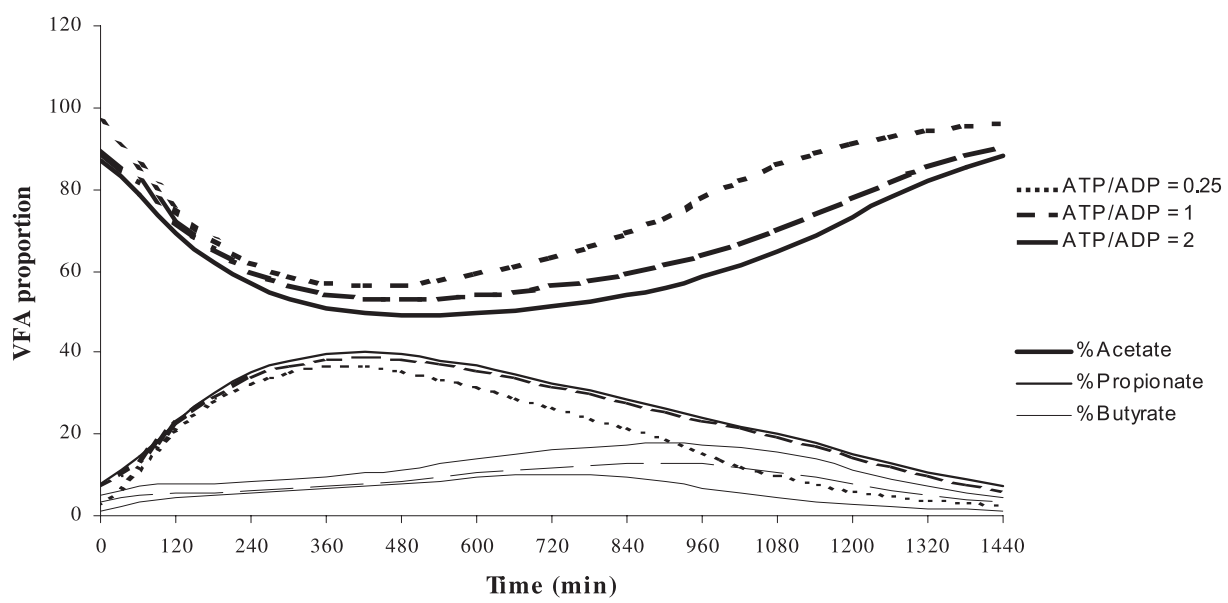

Figure 6. VFA sensitivity to initial ATP/ADP ratio.

production leads normally to a rapid drop in $\mathrm{pH}$ followed later by an increase in $\mathrm{pH}$. A delay probably occurred in the model where $\mathrm{H}^{+}$ions were involved in acidobasic equilibrium after the formation of anions by the various metabolic pathways. This aspect challenges a next version of the model to correct for this delay.

The diurnal variation of the energy and the oxidation-reduction status in the rumen was satisfactorily predicted. The kinetics of ATP/ADP and NADH/NAD ratios well represented energy intake by feeding followed by energy utilization by microorganisms. The ATP/ADP ratio ranged between 0.1 and 5 . The sensitivity of the VFA molar proportions to the initial ratio was considerable as illustrated in Figure 6 with different initial ratios of 0.25 , 1 and 2. Typical rumen conditions correspond to a ratio of 0.25 . Acetate production was favored at the beginning when the energy status of the ecosystem was low. This could be explained because ATP production per mole of carbon as VFA was more important in the case of acetate formation than for the other VFA. With the simulations, the redox potential ranged from 0.4 to $-0.3 \mathrm{mV}$, which is fairly realistic.
The lowest redox potential was observed before feeding; which is similar to experimental observations $[5,22]$. Similar to what was observed for the ATP/ADP ratio, the sensitivity of the VFA profile to initial NADH/NAD ratio was considerable. The NADH/NAD ratio had a large influence on VFA partitioning. When the ratio was below 1, butyrate production was favored whereas acetate production decreased.

\subsection{Study of methanogenesis and acetogenesis partition}

Simulated fluxes for acetogenesis and methanogenesis (Fig. 7) were low compared to observed data. Acetogenesis always remained lower than methanogenesis, similar to what is observed in the rumen. Moreover, these two fluxes varied in the same direction and are closely linked with variations in NADH and NAD. Regarding gas production, model predictions were unsatisfactory because predicted methane production was too low. An inappropriate representation for the gas outflow rates is likely the cause of this. However, little data is available concerning the kinetics of gas production. 
Acetogenesis

Methanogenesis

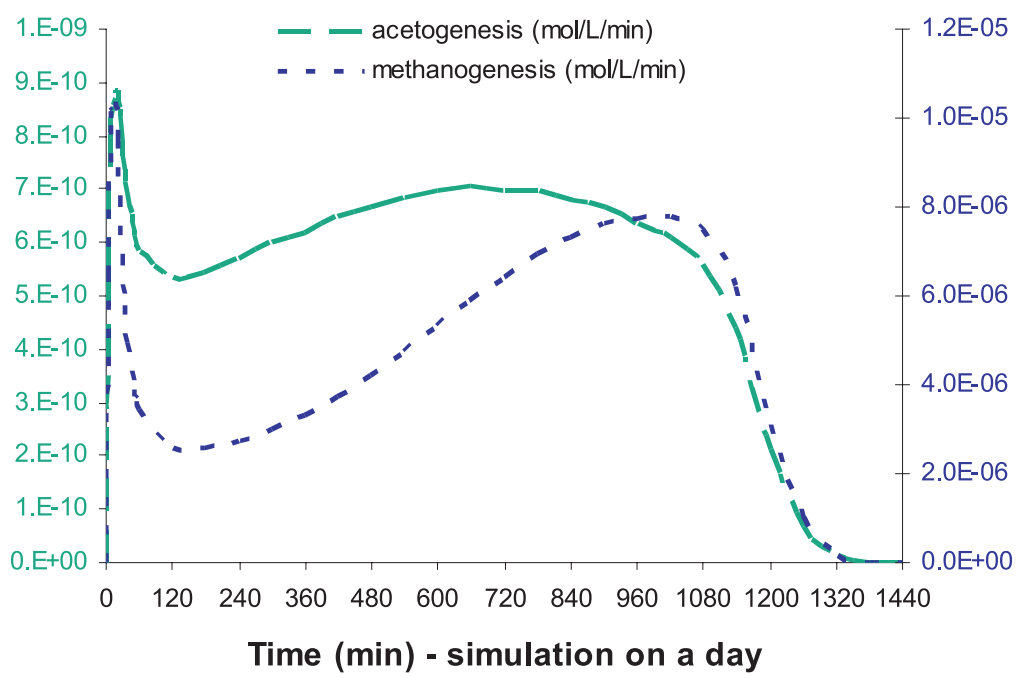

Figure 7. Simulated fluxes of acetogenesis and methanogenesis.

\section{DISCUSSION}

\subsection{Potential and limits of the model}

Until now, attempts to consider thermodynamic laws in rumen modeling have been scarce and not exhaustive [17]. The approach taken in this study is therefore original, integrating the major thermodynamic laws to model the fermentation processes in a mechanistic way. This approach was a first attempt to describe the biochemical equilibrium and to determine $\mathrm{pH}$ and redox potential. The ability of thermodynamic models to explain some ruminal digestive phenomena is highlighted. The results of the simulations were satisfactory and seemed realistic. The model was constructed based on sound biochemical information and integrated the major known regulations by the ratios of ATP/ADP and NADH/NAD. These cofactors are involved in numerous metabolic pathways and may interact with the intensity of rumen fermentation. This current study expands on that proposed by Sauvant et al. [34]. In addition to the before mentioned cofactors, rumen $\mathrm{pH}$ and redox potential had a major impact on the equilibrium of fermentation.

Some aspects of the model were not satisfactory. The convergence of the redox potentials of the different reactions over time was not reached even for simulation lengths of ten days. Indeed, the range of rumen redox potential could be extensive $[5,24]$ and this parameter might influence metabolic activities [7] and therefore the concentrations of the different oxidation-reduction molecules. However, it is likely that the range of values provided by the model does not influence the global microbial activities [23]. The lack of convergence can be explained in open systems, like the rumen, which exchange matter with the surrounding area and that likely never reach thermodynamic equilibrium [39]. This result underlines that, in a context of an open system, it is necessary to cautiously apply the thermodynamic laws described for closed systems. Proton and electron transfers are closely linked. The proton motive force created by 
the accumulation of $\mathrm{H}^{+}$on one side of a cell membrane and not the other can also be responsible for the lack of convergence of the redox potentials [6]. This aspect of $\mathrm{H}^{+}$metabolism should be better represented. The simulated $\mathrm{pH}$ differed from expectations and this could probably be due to a poor representation of acid dissociation reactions or of buffer-acid reactions, this could also be the outcome of an insufficient consideration of the role of bicarbonate [16]. Moreover, it would be interesting to modulate VFA absorption relative to $\mathrm{pH}$. Pitt and Pell [30] proposed another approach to model rumen $\mathrm{pH}$ fluctuations from the ruminal buffer index (saliva production) and the deviation in rumen acidity (from VFA and lactate production).

Finally, it is important to point out that, by construction, the model was non linear. The size and the turnover of the compartments varied to a great extent. These two properties made the model very sensitive and difficult to parameterize.

\subsection{Proposals for further developments}

At this stage, it seems important to integrate a minimum of other information in the model by identifying characteristics that are not determined directly by thermodynamic laws. There is a need to include additional constraints in the model, and inclusion of kinetic laws appears to be the most relevant. Kinetic laws would help to define parameters like the rates of product formation (for instance, these reaction rates could depend on the influence of enzymes or co-factors on the reactions). In terms of fluxes of elements, mass action laws were only considered in the model. This study also highlighted the interest of experimental studies on the influence of change in concentrations of cofactors. However, little experimental data is available on this subject. The ATP/ADP and NADH/NAD ratios had a main influence on fermentation pathways, therefore, it seems necessary to better quantify the microbial specific requirements for ATP and NADH $[13,14]$. More in vitro studies on the intracellular NAD/NADH ratio could bring valuable information [15]. This study also raises some questions for modeling microbial dynamics $[12,26]$. When several microbial groups are involved, responses of population ecology are important to deal with the dynamics of populations of living organisms. Rumen bacteria can be classified in several homogeneous groups according to metabolic criteria, end-products of fermentation, sensitivity to change in redox potential or $\mathrm{pH}$ [35]. These parameters could be taken into account when building models of microbial populations. Ideally, a global model combining these sub-models could be developed with both thermodynamic laws (as the first assumption for a multi-species system) and the known interactions among different microbial species (responses of population ecology). Another issue raised by this study concerns the distinction of several rumen compartments. Indeed, fermentation takes place inside of microbial cells. The conditions there could be entirely different from the extracellular ruminal fluid conditions (e.g., pH may be quite different). Our approach made no difference between intracellular and extracellular levels. Though there are few quantitative data on the relations among different rumen compartments, it would be interesting to better characterize and possibly to distinguish a soluble fraction, a gaseous fraction, a contact area between dietary particles and microorganisms, and finally the rumen wall [8]. Various aspects of the model require further investigation, like the evaluation of the model sensitivity to some assumptions (compartment initial concentrations, reverse reaction rates); however, the results show that the integration of thermodynamic laws in rumen models would certainly help to better predict fermentation pathways. 


\section{CONCLUSION}

The model favors reactions following thermodynamic principles. Reaction rates are determined by their change in Gibbs energy. The reactions are supposed to be reversible and evolve along a decrease in Gibbs energy. Tables of standard Gibbs energy for the different components, after adjustment to rumen temperature, allow determining the various necessary constants. Reverse reaction rates were determined arbitrarily, which is a strong limit of this model. The model simulations adequately represented the post feeding evolution of the main VFA concentration. Thermodynamic laws were therefore helpful to understand fermentation pathways. The model was developed to be included in whole rumen models, or to be completed by incorporating new reactions. However, difficulties arise during model development because the system is open and gathers a large network of metabolic reactions. This makes the model very sensitive. Some results were not entirely satisfactory, especially for $\mathrm{pH}$ and redox potential. As represented, the thermodynamic laws were not sufficient to explain all observed variation. Other driving forces from kinetics and population ecology should also be taken into account, especially to modulate forward and reverse reaction rates.

\section{REFERENCES}

[1] Alberty R.A., Calculation of standard transformed Gibbs energies and standard transformed enthalpies of biochemical reactants, Arch. Biochem. Biophys. 353 (1998) 116130.

[2] Baldwin R.L., Thornley J.H., Beever D.E., Metabolism of the lactating cow II. Digestive elements of a mechanistic model, J. Dairy Res. 54 (1987) 107-131.

[3] Bannink A., Visser H.D., Comparison of mechanistic rumen models on mathematical formulation of extramicrobial and microbial processes, J. Dairy Sci. 80 (1997) 12961314.
[4] Baran M., The fermentation of glucose in small artificial rumen, Arch. Tierernähr. 32 (1982) 779-788.

[5] Barry T.N., Thompson A., Armstrong D.G., Rumen fermentation studies on two contrasting diets, J. Agr. Sci. 89 (1977) 183-195.

[6] Bond D.R., Russel J.B., Relationship between intracellular phosphate, proton motive force, and rate of nongrowth energy dissipation (energy spilling) in streptococcus bovis JB1, Appl. Environ. Microb. (1998) 976981.

[7] Counotte G.H.M., de Groot M., Prins A., Kinetic parameters of lactate dehydrogenases of some rumen bacterial species, the anaerobic ciliate Isotricha prostoma and mixed rumen microorganisms, Anton. Leeuw. 46 (1980) 363-381.

[8] Czerkawski J.W., Cheng K.J., Compartmentation in the rumen, in: Hobson P.N. (Ed.), The Rumen Microbial Ecosystem, Elsevier Applied Science, 1988, pp. 361-386.

[9] Dijkstra J., Mathematical modelling and integration of rumen fermentation processes, Ph.D. thesis, department of Animal Nutrition, Wageningen Agricultural University, 1993, $221 \mathrm{p}$.

[10] Dijkstra J., Production and absorption of volatile fatty acids in the rumen, Livest. Prod. Sci. 39 (1994) 61-69.

[11] Dijkstra J., France J., A comparative evaluation of models of whole rumen function, in: Methods in Modelling Herbivore Nutrition, Paris, France, 1995, 31 p.

[12] Dijkstra J., Mills J.A.N., France J., The role of dynamic modelling in understanding the microbial contribution to rumen function, Nutr. Res. Rev. 15 (2002) 67-90.

[13] Erfle J.D., Sauer F.D., Mahadevan S., Energy metabolism in rumen microbes, in: Milligan L.P., Grovum W.L., Dobson A. (Eds.), Control of Digestion and Metabolism in Ruminants, Prentice Hall, 1986, pp. 81-99.

[14] Heijnen J.J., van Dijken J.P., In search of a thermodynamic description of biomass yields for the chemotrophic growth of microorganisms, Biotechnol. Bioeng. 39 (1992) 833-858.

[15] Hino T., Russell J.B., Effect of reducingequivalent disposal and NADH/NAD on deamination of amino acids by intact rumen microorganisms and their cell extracts, Appl. Environ. Microb. 50 (1985) 1368-1374.

[16] Kohn R.A., Dunlap T.F., Calculation of the buffering capacity of bicarbonate in the 
rumen and in vitro, J. Anim. Sci 76 (1998) 1702-1709.

[17] Kohn R.A., Boston R.C., The role of thermodynamics in controlling rumen metabolism, in: McNamara J.P., France J., Beever D.E. (Eds.), Modelling Nutrient Utilization in Farm Animals, CAB international, 2000, pp. 11-24.

[18] Laidler K.J., Physical Chemistry with Biological Applications, Addison Wesley, 1980, 587 p.

[19] Lescoat P., Sauvant D., Development of a mechanistic model for rumen digestion validated using the duodenal flux of amino acids, Reprod. Nutr. Dev. 35 (1995) 45-70.

[20] Lovatto P.A., Sauvant D., Modeling homeorhetic and homeostatic controls of pig growth, J. Anim. Sci. 81 (2003) 683-696.

[21] Maaroufi C., Giger-Reverdin S., Sauvant D., Relationships between post-prandial $\mathrm{pH}$ drop and rumen soluble carbohydrates concentration, Reprod. Nutr. Dev. 40 (2000) 208.

[22] Marounek M., Bartos S., Kalachnyuk G.I., Dynamics of the redox potential and $\mathrm{rH}$ of the rumen fluid of goats, Physiol. Bohemoslov. 31 (1982) 369-374.

[23] Marounek M., Wallace J., Influence of culture $E_{h}$ on the growth and metabolism of the rumen bacteria selenomonas ruminantium, bacteroides amylophilus, bacteroides succinogenes and streptococcus bovis in batch culture, J. Gen. Microbi. 130 (1984) 223 229.

[24] Marounek M., Roubal P., Bartos S., The redox potential, $\mathrm{rH}$ and $\mathrm{pH}$ values in the gastrointestinal tract of small ruminants, Physiol. Bohemoslov. 36 (1987) 71-74.

[25] Metzler D.E., Biochemistry: the chemical reactions of living cells, Academic Press, New York, 1977, 1129 p.

[26] Murphy M.R., Sauvant D., Meta-analysis of interactions between major rumen fibrolytic bacteria in solubilizing and utilizing substrates, (submitted 2004).

[27] Offner A., Sauvant D., Digestive interactions: responses to some variations of the amount of starch digestible in the rumen, in: Book of abstracts of the 53rd Annual Meeting of the EAAP No. 8, Cairo, Egypt, 1-4 September 2002, p. 57.
[28] Offner A., Sauvant D., Comparative evaluation of the Molly, CNCPS and LES rumen models, Anim. Feed Sci. Technol. 112 (2004) 107-130.

[29] Offner A., Bach A., Sauvant D., Modeling starch digestion in the rumen: a comparative approach, J. Anim. Sci. 80 (Suppl. 1) (2002) p. 184

[30] Pitt R.E., Pell A.N., Modeling ruminal pH fluctuations: interactions between meal frequency and digestion rate, J. Dairy Sci. 80 (1997) 2429-2441.

[31] Pugh-Roberts, Professional Dynamo Plus, Reference manual, Pugh-Roberts Associates, Cambridge, MA, 1986.

[32] Russell J.B., O’Connor J.D., Fox D.G., van Soest P.J., Sniffen C.J., A net carbohydrate and protein system for evaluating cattle diets: I. Ruminal fermentation, J. Anim. Sci. 70 (1992) 3551-3561.

[33] Sauvant D., Dijkstra J., Mertens D. Optimisation of ruminal digestion: a modelling approach, in: Journet M., Grenet E., Farce M.-H., Thériez M., Demarquilly C. (Eds.), Recent developments in the nutrition of herbivores, INRA éditions, 1995, pp. 143-165.

[34] Sauvant D., van Milgen J., Lescoat P., Modélisation de la régulation de la stoechiométrie des fermentations ruminales par la disponibilité en ATP et en $\mathrm{NADH}_{2}$, Ann. Zootech. 44 (Suppl. 1) (1995) 167.

[35] Stewart C.S., Bryant M.P., The rumen bacteria, in: Hobson P.N. (Ed.), The Rumen Microbial Ecosystem, Elsevier Applied Science, 1988, pp. 21-76.

[36] Stull D.R., Westrum E.F., Sinke G.C., The Chemical Thermodynamics of Organic Compounds, Wiley J., NY, 1969, 865 p.

[37] Tinoco I., Sauer K., Wang J.C., Physical Chemistry: principles and applications in biological sciences, Prentice Hall, 2nd ed., $1985,706 \mathrm{p}$.

[38] van Milgen J., Modeling biochemical aspects of energy metabolism in mammals, J. Nutr. 132 (2002) 3195-3202.

[39] Zilbergleyr B.J., Thermodynamic equilibrium in open chemical systems, Chem. Physics, LANL printed archives, 2000. 


\section{Appendix: Parameter values and list of equations of the thermodynamic model.}

\section{PARAMETERS}

\begin{tabular}{|c|c|c|c|c|c|}
\hline $\mathrm{ST}=0$ & Starch & $\mathrm{ACE}=0.07$ & Acetate & $\mathrm{H} 2=0.0005$ & Hydrogen \\
\hline $\mathrm{CW}=0.05$ & Cell wall & $\mathrm{ACA}=1 \mathrm{E}-3$ & Acetic acid & $\mathrm{HCO} 3=0.08$ & Bicarbonate ion \\
\hline $\mathrm{GLU}=1 \mathrm{E}-4$ & Glucose & $\mathrm{BUT}=0.01$ & Butyrate & HPLUS $=3 \mathrm{E}-7$ & Proton \\
\hline $\mathrm{PYR}=1 \mathrm{E}-8$ & Pyruvate & $\mathrm{ACB}=2 \mathrm{E}-4$ & Butyric acid & $\mathrm{NADH}=1 \mathrm{E}-3$ & Reduced nicotinamide adenine dinucleotide \\
\hline $\mathrm{LAC}=1 \mathrm{E}-3$ & Lactate & $\mathrm{VAL}=0.0008$ & Valerate & $\mathrm{NAD}=1 \mathrm{E}-3$ & Nicotinamide adenine dinucleotide \\
\hline $\mathrm{ACL}=2 \mathrm{E}-6$ & Lactic acid & $\mathrm{ACV}=2 \mathrm{E}-4$ & Valeric acid & $\mathrm{ATP}=1.5 \mathrm{E}-3$ & Adenosine triphosphate \\
\hline $\mathrm{PRO}=0.02$ & Propionate & $\mathrm{CH} 4=0.3$ & Methane & $\mathrm{ADP}=1.5 \mathrm{E}-3$ & Adenosine diphosphate \\
\hline $\mathrm{ACP}=4 \mathrm{E}-4$ & Propionic acid & $\mathrm{CO} 2=0.7$ & Carbon dioxide & $\mathrm{MDM}=2$ & Microbial dry matter \\
\hline
\end{tabular}

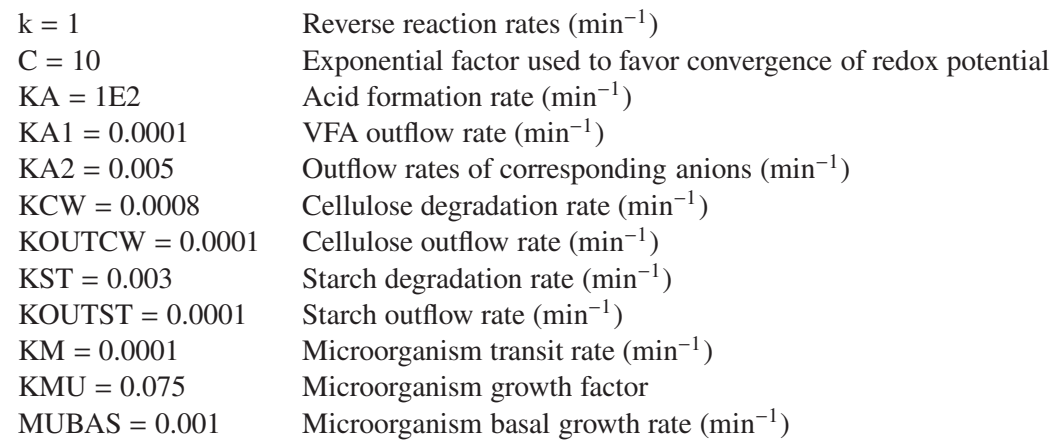

Faraday constant

Gas constant Temperature in Kelvin Standard Gibbs energy change for ATP formation at $\mathrm{pH}=0$

\footnotetext{
$\mathrm{EvOV}=0.512$ Pyruvate/Valerate

$\mathrm{EvOL}=0.418$ Lactate/Propionate

EvOPP $=0.318$ Pyruvate/Propionate

$\mathrm{EvOP}=0.229$ Pyruvate/Lactate

$\mathrm{EvOCO} 2 \mathrm{ch}=0.170 \mathrm{CO}_{2} / \mathrm{CH}_{4}$

$\mathrm{EvOCO} 2 \mathrm{ac}=0.124 \mathrm{CO}_{2} /$ Acetate

$\mathrm{EvOH}=0 \mathrm{H}^{+} / \mathrm{H}_{2}$

$\mathrm{EvON}=-0.113 \mathrm{NAD} / \mathrm{NADH}$

$\mathrm{EvOA}=-0.228$ Acetate/Pyruvate

EvOG $=-0.290$ Pyruvate/Glucose
}

Redox potentials values in standard conditions $(\mathrm{pH}=0, T=298 \mathrm{~K})$

$$
\begin{aligned}
& \text { pKa values of the acids } \\
& \text { pKhco }=7.74 \mathrm{HCO}_{3}^{-} \\
& \text {pKlac }=3.86 \text { Lactate }^{-} \\
& \text {pKpro }=4.87 \text { Propionate } \\
& \text { pKace }=4.75 \text { Acetate } \\
& \text { pKbut }=4.82 \text { Butyrate } \\
& \text { pKval }=4.84 \text { Valerate }
\end{aligned}
$$

\section{COMPARTMENTS AND FLOWS}

Cell wall compartment: $\mathbf{C W}$

$\mathrm{dCW} / \mathrm{dt}=\mathrm{INCW}-\mathrm{CWGLU}-\mathrm{OUTCW}$

INCW $=$ PULSE $(50 / 180,1,0,1440)$

$\mathrm{CWGLU}=\mathrm{KCW} \times \mathrm{CW}$

OUTCW $=$ KOUTCW $\times \mathrm{CW}$ 
Starch compartment: ST

$\mathrm{dST} / \mathrm{dt}=\mathrm{INST}-\mathrm{STGLU}-$ OUTST

INST $=$ PULSE $(25 / 180,1,0,1440)$

STGLU $=$ KST $\times$ ST

OUTST $=$ KOUTST $\times$ ST

Glucose compartment: GLU

$\mathrm{dGLU} / \mathrm{dt}=\mathrm{CWGLU}+\mathrm{STGLU}+\mathrm{PYGL}-\mathrm{GLPY}-\mathrm{OUTGLU}$

OUTGLU $=0.0001 \times$ GLU

Glucose-pyruvate (1)

$\mathrm{GLPY}=2 \mathrm{E} 10 \times \mathrm{GLU} \times \mathrm{NAD}^{2} \times \mathrm{ADP}^{2} \times \mathrm{EXP}(\mathrm{C} \times \mathrm{DEGLU})$

$\mathrm{PYGL}=(2 \mathrm{E} 10 / \mathrm{Keq} 1) \times \mathrm{PYR}^{2} \times \mathrm{NADH}^{2} \times \mathrm{ATP}^{2} \times \mathrm{EXP}(-\mathrm{C} \times$ DEGLU $)$

Pyruvate compartment: PYR

$\mathrm{dPYR} / \mathrm{dt}=2 \mathrm{GLPY}-2 \mathrm{PYGL}+\mathrm{ACPY}-\mathrm{PYAC}+\mathrm{LAPY}-\mathrm{PYLA}+2 \mathrm{BUPY}-2 \mathrm{PYBU}+$ PROPY - PYPRO + 2VALPY - 2PYVAL - PYMIC - OUTPY

OUTPY $=$ KA2 $\times$ PYR

Pyruvate-lactate (2)

$\mathrm{PYLA}=\mathrm{k} \times \mathrm{PYR} \times \mathrm{NADH} \times \mathrm{EXP}(\mathrm{C} \times \mathrm{DEPYR})$

$\mathrm{LAPY}=(\mathrm{k} / \mathrm{Keq} 2) \times \mathrm{LAC} \times \mathrm{NAD} \times \mathrm{EXP}(-\mathrm{C} \times \mathrm{DEPYR})$

Pyruvate-propionate (4) via succinate

$\mathrm{PYPRO}=100 \times \mathrm{k} \times \mathrm{PYR} \times \mathrm{ADP} \times \mathrm{NADH}^{2} \times \mathrm{EXP}(\mathrm{C} \times \mathrm{DEPRO})$

$\mathrm{PROPY}=(100 \times \mathrm{k} / \mathrm{Keq} 4) \times \mathrm{PRO} \times \mathrm{ATP} \times \mathrm{NAD}^{2} \times \mathrm{EXP}(-\mathrm{C} \times \mathrm{DEPRO})$

Pyruvate-acetate (5)

$\mathrm{PYAC}=10000 \times \mathrm{k} \times \mathrm{PYR} \times \mathrm{NAD} \times \mathrm{ADP} \times \mathrm{EXP}(\mathrm{C} \times \mathrm{DEACE})$

$\mathrm{ACPY}=(10000 \times \mathrm{k} / \mathrm{Keq} 5) \times \mathrm{ACE} \times \mathrm{NADH} \times \mathrm{CO} 2 \times \mathrm{ATP} \times \mathrm{EXP}(-\mathrm{C} \times \mathrm{DEACE})$

Pyruvate-butyrate (6)

$\mathrm{PYBU}=1000 \times \mathrm{k} \times \mathrm{PYR}^{2} \times \mathrm{ADP}$

$\mathrm{BUPY}=(1000 \times \mathrm{k} / \mathrm{Keq} 6) \times \mathrm{BUT} \times \mathrm{ATP} \times \mathrm{CO}^{2}$

Pyruvate-valerate (7)

PYVAL $=\mathrm{k} \times \mathrm{PYR}^{2} \times \mathrm{NADH}^{3} \times \mathrm{EXP}(\mathrm{C} \times \mathrm{DEVAL})$

$\mathrm{VALPY}=(\mathrm{k} / \mathrm{Keq} 7) \times \mathrm{VAL} \times \mathrm{CO} 2 \times \mathrm{NAD}^{3} \times \mathrm{EXP}(-\mathrm{C} \times \mathrm{DEVAL})$

Lactate compartment: LAC

$\mathrm{dLAC} / \mathrm{dt}=-\mathrm{LAPY}+\mathrm{PYLA}-\mathrm{LAPRO}+\mathrm{PROLA}-\mathrm{LACA}+\mathrm{ALAC}-\mathrm{OUTLAC}$

OUTLAC $=\mathrm{KA} 2 \times \mathrm{LAC}$

Lactate-propionate (3)

$\mathrm{LAPRO}=\mathrm{k} \times \mathrm{LAC} \times \mathrm{NADH} \times \mathrm{EXP}(\mathrm{C} \times \mathrm{DELAC})$

$\mathrm{PROLA}=(\mathrm{k} / \mathrm{Keq} 3) \times \mathrm{PRO} \times \mathrm{NAD} \times \mathrm{EXP}(-\mathrm{C} \times \mathrm{DELAC})$

Lactic acid formation (12)

LACA $=\mathrm{ka} \times$ LAC $\times$ HPLUS

$\mathrm{ALAC}=(\mathrm{ka} / \mathrm{Keq} 12) \times \mathrm{ACL}$ 
Lactic acid compartment: ACL

$\mathrm{dACL} / \mathrm{dt}=-\mathrm{ALAC}+\mathrm{LACA}-\mathrm{OUTACL}$

OUTACL $=$ KA $1 \times$ ACL

Propionate compartment: PRO

$\mathrm{dPRO} / \mathrm{dt}=\mathrm{LAPRO}-\mathrm{PROLA}+\mathrm{PYPRO}-\mathrm{PROPY}+\mathrm{APRO}-\mathrm{PROA}-\mathrm{OUTPRO}$

OUTPRO $=\mathrm{KA} 2 \times$ PRO

Propionic acid formation (13)

$\mathrm{PROA}=\mathrm{ka} \times \mathrm{PRO} \times$ HPLUS

$\mathrm{APRO}=(\mathrm{ka} / \mathrm{keq} 13) \times \mathrm{ACP}$

Propionic acid compartment: ACP

$\mathrm{dACP} / \mathrm{dt}=-\mathrm{APRO}+\mathrm{PROA}-\mathrm{OUTACP}$

$\mathrm{OUTACP}=\mathrm{KA} 1 \times \mathrm{ACP}$

Acetate compartment: ACE

$\mathrm{dACE} / \mathrm{dt}=\mathrm{PYAC}-\mathrm{ACPY}+\mathrm{COACE}-\mathrm{ACECO}+\mathrm{AACE}-\mathrm{ACEA}-\mathrm{OUTACE}$

OUTACE $=\mathrm{KA} 2 \times \mathrm{ACE}$

Acetic acid formation (14)

ACEA $=\mathrm{ka} \times$ ACE $\times$ HPLUS

$\mathrm{AACE}=(\mathrm{ka} / \mathrm{Keq} 14) \times \mathrm{ACA}$

Acetic acid compartment: ACA

$\mathrm{dACA} / \mathrm{dt}=-\mathrm{AACE}+\mathrm{ACEA}-$ OUTACA

OUTACA $=$ KA $1 \times$ ACA

Butyrate compartment: BUT

$\mathrm{dBUT} / \mathrm{dt}=\mathrm{PYBU}-\mathrm{BUPY}+\mathrm{ABUT}-\mathrm{BUTA}-\mathrm{OUTBUT}$

OUTBUT $=$ KA $2 \times$ BUT

Butyric acid formation (15)

BUTA $=\mathrm{ka} \times$ BUT $\times$ HPLUS

$\mathrm{ABUT}=(\mathrm{ka} / \mathrm{Keq} 15) \times \mathrm{ACB}$

Butyric acid compartment: $\mathrm{ACB}$

$\mathrm{dACB} / \mathrm{dt}=-\mathrm{ABUT}+\mathrm{BUTA}-\mathrm{OUTACB}$

$\mathrm{OUTACB}=\mathrm{KA} 1 \times \mathrm{ACB}$

Valerate compartment: VAL

$\mathrm{dVAL} / \mathrm{dt}=\mathrm{PYVAL}-\mathrm{VALPY}+\mathrm{AVAL}-\mathrm{VALA}-\mathrm{OUTVAL}$

OUTVAL $=$ KA2 $\times$ VAL

Valeric acid formation (16)

VALA $=\mathrm{ka} \times \mathrm{VAL} \times$ HPLUS

$\mathrm{AVAL}=(\mathrm{ka} / \mathrm{Keq} 16) \times \mathrm{ACV}$

Valeric acid compartment: ACV

$\mathrm{dACV} / \mathrm{dt}=-\mathrm{AVAL}+\mathrm{VALA}-\mathrm{OUTACV}$

$\mathrm{OUTACV}=\mathrm{KA} 1 \times \mathrm{ACV}$ 
Carbon dioxide compartment: $\mathrm{CO} 2$

$\mathrm{dCO} 2 / \mathrm{dt}=\mathrm{PYAC}-\mathrm{ACPY}+\mathrm{CH} 4 \mathrm{CO}-\mathrm{COCH} 4+2 \mathrm{ACECO}-2 \mathrm{COACE}+\mathrm{HCCO}-$ $\mathrm{COHC}+2 \mathrm{PYBU}-2 \mathrm{BUPY}+\mathrm{PYVAL}-\mathrm{VALPY}-\mathrm{OUTCO} 2$

OUTCO2 = CLIP $($ XCO2,0,PRES, 1$)$

CO2-METHAN (8)

$\mathrm{COCH} 4=100 \times \mathrm{k} \times \mathrm{CO} 2 \times \mathrm{NADH}^{4} \times \mathrm{ADP} \times \mathrm{EXP}(\mathrm{C} \times \mathrm{DECO} 2 \mathrm{CH})$

$\mathrm{CH} 4 \mathrm{CO}=(100 \times \mathrm{k} / \mathrm{Keq} 8) \times \mathrm{CH} 4 \times \mathrm{NAD}^{4} \times \mathrm{ATP} \times \mathrm{EXP}(-\mathrm{C} \times \mathrm{DECO} 2 \mathrm{CH})$

CO2-ACETATE (9)

$\mathrm{COACE}=\mathrm{k} \times \mathrm{CO}^{2} \times \mathrm{NADH}^{4} \times \mathrm{ADP}^{0.25} \times \mathrm{EXP}(\mathrm{C} \times \mathrm{DECO} 2 \mathrm{AC})$

$\mathrm{ACECO}=(\mathrm{k} / \mathrm{Keq} 9) \times \mathrm{ACE} \times \mathrm{NAD}^{4} \times \mathrm{ATP}^{0.25} \times \mathrm{EXP}(-\mathrm{C} \times \mathrm{DECO} 2 \mathrm{AC})$

Dissociation and relation $\mathrm{CO} 2-\mathrm{HCO} 3$ (11)

$\mathrm{HCCO}=\mathrm{k} \times \mathrm{HCO} 3 \times$ HPLUS

$\mathrm{COHC}=(\mathrm{k} / \mathrm{Keq} 11) \times \mathrm{CO} 2$

Methane compartment: $\mathrm{CH} 4$

$\mathrm{dCH} 4 / \mathrm{dt}=\mathrm{COCH} 4-\mathrm{CH} 4 \mathrm{CO}-\mathrm{OUTCH} 4$

OUTCH4 = CLIP $(\mathrm{XCH} 4,0, \mathrm{PRES}, 1)$

Hydrogen compartment: $\mathrm{H} 2$

$\mathrm{dH} 2 / \mathrm{dt}=\mathrm{HPH} 2-\mathrm{H} 2 \mathrm{HP}-\mathrm{OUTH} 2$

OUTH2 $=$ CLIP $(0,0$, PRES, 1$)$

$H 2-H+(10)$

$\mathrm{H} 2 \mathrm{HP}=\mathrm{k} \times \mathrm{H} 2 \times \mathrm{NAD} \times \mathrm{EXP}(\mathrm{C} \times \mathrm{DEH})$

$\mathrm{HPH} 2=(\mathrm{k} / \mathrm{Keq} 10) \times \mathrm{HPLUS} \times \mathrm{NADH} \times \mathrm{EXP}(-\mathrm{C} \times \mathrm{DEH})$

Bicarbonate ions compartment: $\mathrm{HCO3}$

$\mathrm{dHCO} 3 / \mathrm{dt}=\mathrm{SALHCO} 3+\mathrm{COHC}-\mathrm{HCCO}$

SALHCO3 $=0.5 \times 10^{-4}$

Salivary flux of bicarbonate ions

$\mathrm{H}^{+}$Compartment: HPLUS

$\mathrm{dHPLUS} / \mathrm{dt}=\mathrm{H} 2 \mathrm{HP}-\mathrm{HPH} 2+\mathrm{AACE}-\mathrm{ACEA}+\mathrm{APRO}-\mathrm{PROA}+\mathrm{ALAC}-\mathrm{LACA}+$ $\mathrm{ABUT}-\mathrm{BUTA}+\mathrm{COHC}-\mathrm{HCCO}+\mathrm{AVAL}-\mathrm{VALA}$

\section{NADH/NAD}

$\mathrm{dNADH} / \mathrm{dt}=\mathrm{NNH}-\mathrm{NHN}$

$\mathrm{dNAD} / \mathrm{dt}=\mathrm{NHN}-\mathrm{NNH}$

$\mathrm{NNH}=2 \mathrm{GLPY}+\mathrm{LAPY}+2 \mathrm{PROPY}+\mathrm{PYAC}+\mathrm{PROLA}+\mathrm{H} 2 \mathrm{HP}+4 \mathrm{CH} 4 \mathrm{CO}+$ $4 \mathrm{ACECO}+3 \mathrm{VALPY}$

$\mathrm{NHN}=2 \mathrm{PYGL}+\mathrm{PYLA}+2 \mathrm{PYPRO}+\mathrm{ACPY}+\mathrm{LAPRO}+\mathrm{HPH} 2+4 \mathrm{COCH} 4+$ 4COACE + 3PYVAL + NADHMM + BESNADHM

\section{ATP/ADP}

$\mathrm{dATP} / \mathrm{dt}=\mathrm{ADTP}-\mathrm{ATDP}$

$\mathrm{ADTP}=2 \mathrm{GLPY}+\mathrm{PYAC}+\mathrm{COCH} 4+0.25 \mathrm{COACE}+\mathrm{PYBU}+\mathrm{PYPRO}$

$\mathrm{ATDP}=2 \mathrm{PYGL}+\mathrm{ACPY}+\mathrm{CH} 4 \mathrm{CO}+0.25 \mathrm{ACECO}+\mathrm{BUPY}+\mathrm{PROPY}+\mathrm{BESATPM}+$ ATPMM $) /\left(1+\left(0.5 \times 10^{-3} / \mathrm{ATP}\right)\right)$

$\mathrm{dADP} / \mathrm{dt}=\mathrm{ATDP}-\mathrm{ADTP}$ 


\section{Microbial compartment}

$\mathrm{dMDM} / \mathrm{dt}=\mathrm{CRMDM}-\mathrm{LYSMDM}-$ OUTMDM

$\mathrm{OUTMDM}=\mathrm{KM} \times \mathrm{MDM}$

$\mathrm{CRMDM}=\mathrm{MUBAS} \times \mathrm{MDM} \times \operatorname{EXP}(\mathrm{KMU} \times(\mathrm{RATDP}-1))$

$\mathrm{LYSMDM}=\mathrm{MUBAS} \times \mathrm{MDM} \times \mathrm{EXP}(-\mathrm{KMU} \times(\mathrm{RATDP}-1))$

BCRMDM $=$ CRMDM - LYSMDM Apparent Growth

$\mathrm{SCRMDM}=\mathrm{RAMP}(\mathrm{BCRMDM}, 0)$

MUAMDM $=60 \times$ BCRMDM/MDM Apparent growth rate in $\mathrm{h}^{-1}$

MURMDM $=60 \times \mathrm{CRMDM} / \mathrm{MDM}$ Real growth rate in $\mathrm{h}^{-1}$

$\mathrm{UTCM}=\mathrm{CRMDM} / 25 \mathrm{C}$ mol used for growth

ATP utilizing flow by microorganisms

ATPMM $=0.001 \times 1.6 \times \mathrm{MDM} / 60$ Maintenance

BESATPM $=$ CRMDM $/ 30$ Growth

C outflow for microorganism growth

$\mathrm{PYMIC}=\mathrm{BCRMDM} / 25 \mathrm{C}$ pyruvate mol used

NADH utilizing flow by microorganisms

$\mathrm{NADHMM}=1 \times 10^{-5} \times$ MDM Maintenance

BESNADHM $=0.5 \times$ UTCM Growth

\section{AUXILIARY VARIABLES}

\section{Ratio NADH/NAD, ATP/ADP}

$\mathrm{RNHN}=\mathrm{NADH} / \mathrm{NAD}$

$\mathrm{RATDP}=\mathrm{ATP} / \mathrm{ADP}$

\section{PH Calculation}

PH $=-\log ($ HPLUS $)$

PHVFA $=6.96-6.94 \times$ SOMVFA

$\mathrm{PHCO} 3=$ pKhco $+\log (\mathrm{HCO} 3 / \mathrm{CO} 2)$

PHACE $=$ pKace $+\log ($ ACE $/$ ACA $)$

PHPRO $=$ pKpro $+\log (\mathrm{PRO} / \mathrm{ACP})$

PHBUT $=$ pKbut $+\log ($ BUT $/ A C B)$

PHLAC $=$ pKlac $+\log ($ LAC $/$ ACL $)$

$\mathrm{PHVAL}=\mathrm{pKval}+\log (\mathrm{VAL} / \mathrm{ACV})$
$\mathrm{pH}$ calculation in a mechanistic way $\mathrm{pH}$ calculation in an empirical way using [VFA] Calculation for each acid using $\mathrm{pKa}$ 


\section{Gas pressures}

$\mathrm{PRES}=\mathrm{CH} 4+\mathrm{CO} 2+\mathrm{H} 2 \quad$ Total pressure in the rumen

$\mathrm{XCH} 4=\mathrm{CH} 4 / \mathrm{PRES} \quad$ Partial pressures

$\mathrm{XCO} 2=\mathrm{CO} 2 / \mathrm{PRES}$

$\mathrm{XH} 2=\mathrm{H} 2 / \mathrm{PRES}$

\section{VFA molar proportions}

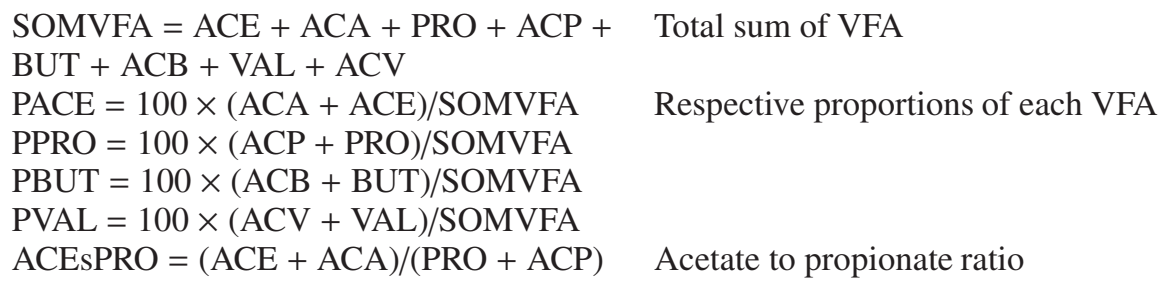

\section{CALCULATION OF THERMODYNAMICAL VARIABLES}

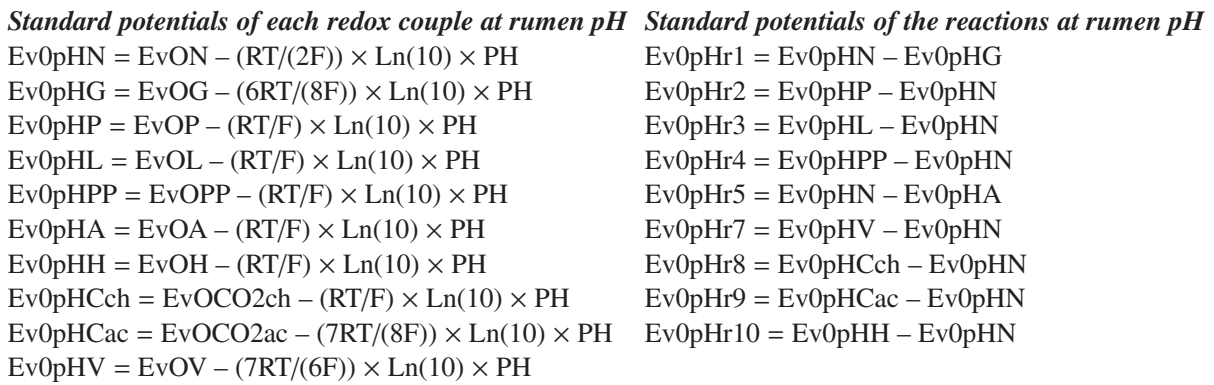

Gibbs energies of the reactions (without ATP couplings) in standard conditions

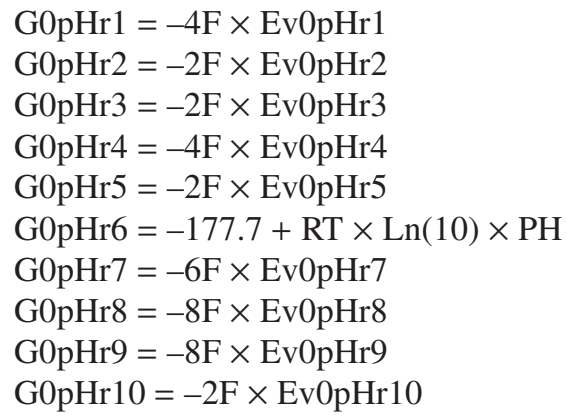

Gibbs energy for ATP formation in standard conditions

$\Delta \mathrm{G}_{0 \mathrm{ATP}} \mathrm{pH}=\Delta \mathrm{G}_{0 \mathrm{ATP}}+\mathrm{RT} \times \operatorname{Ln}(10) \times \mathrm{PH}$ 
Gibbs energies of the reactions in rumen conditions

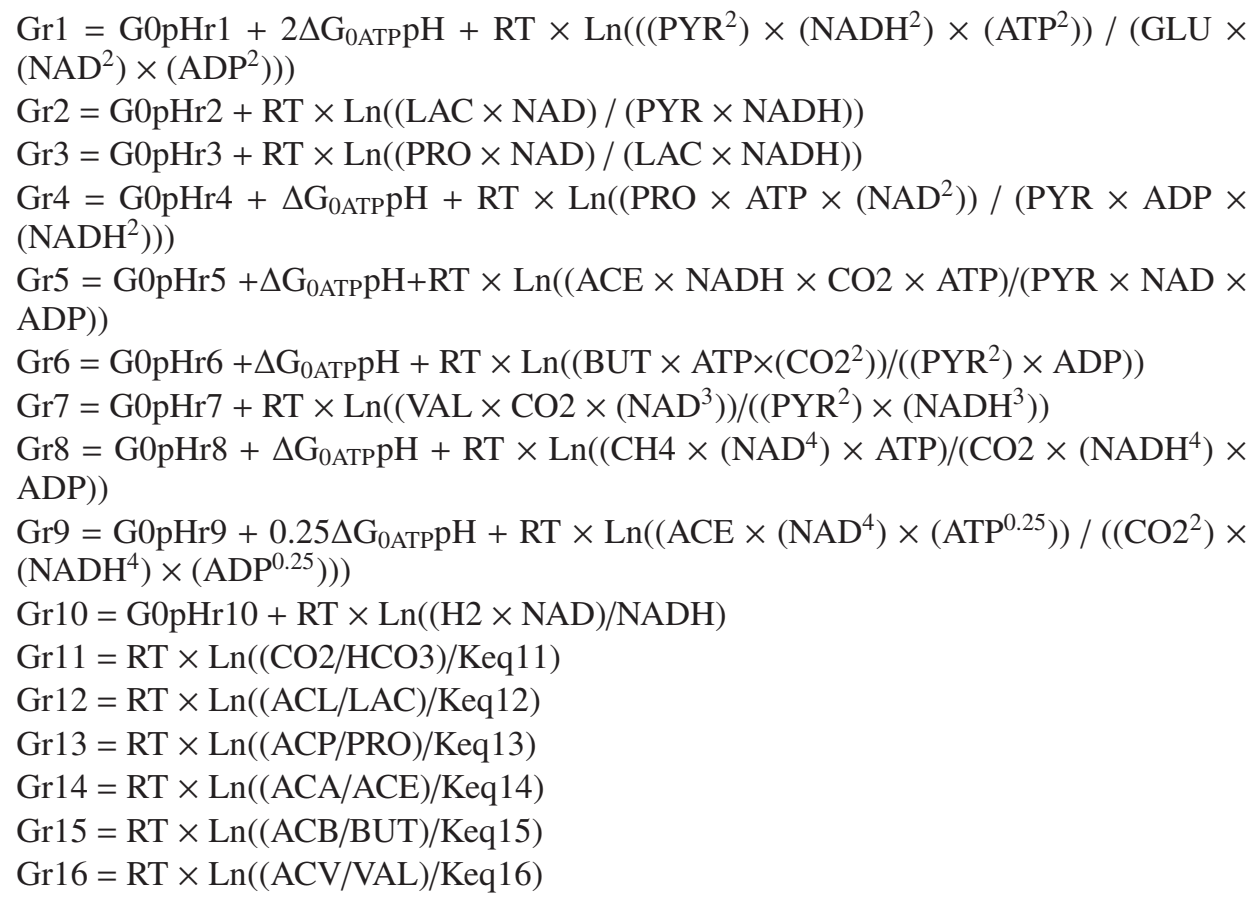

\section{Equilibrium constants of the reactions}

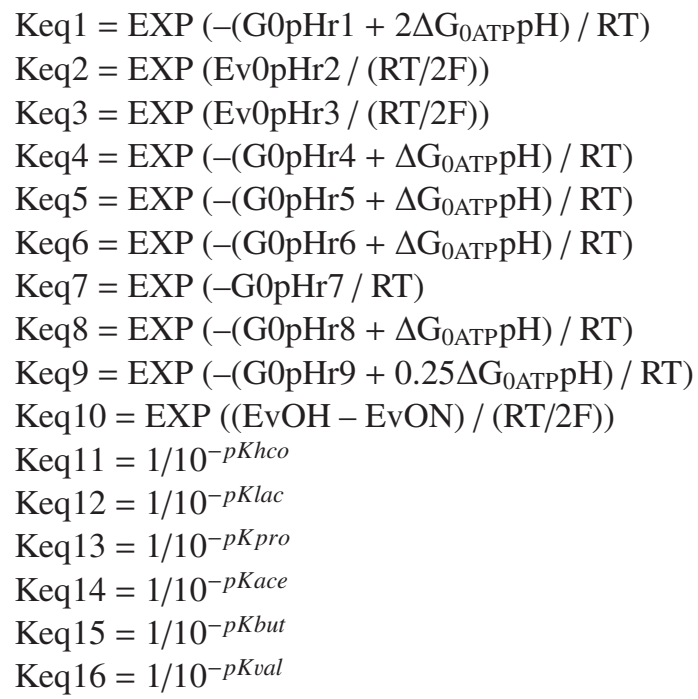




\section{Potential values of each couple}

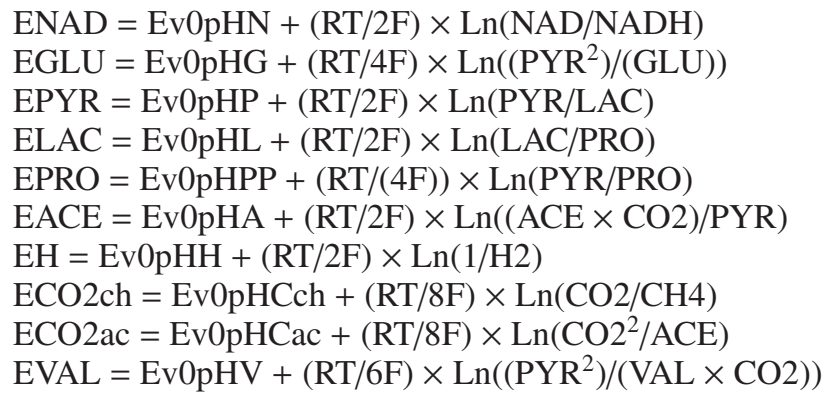

\section{Determination of the average redox potential in the rumen}

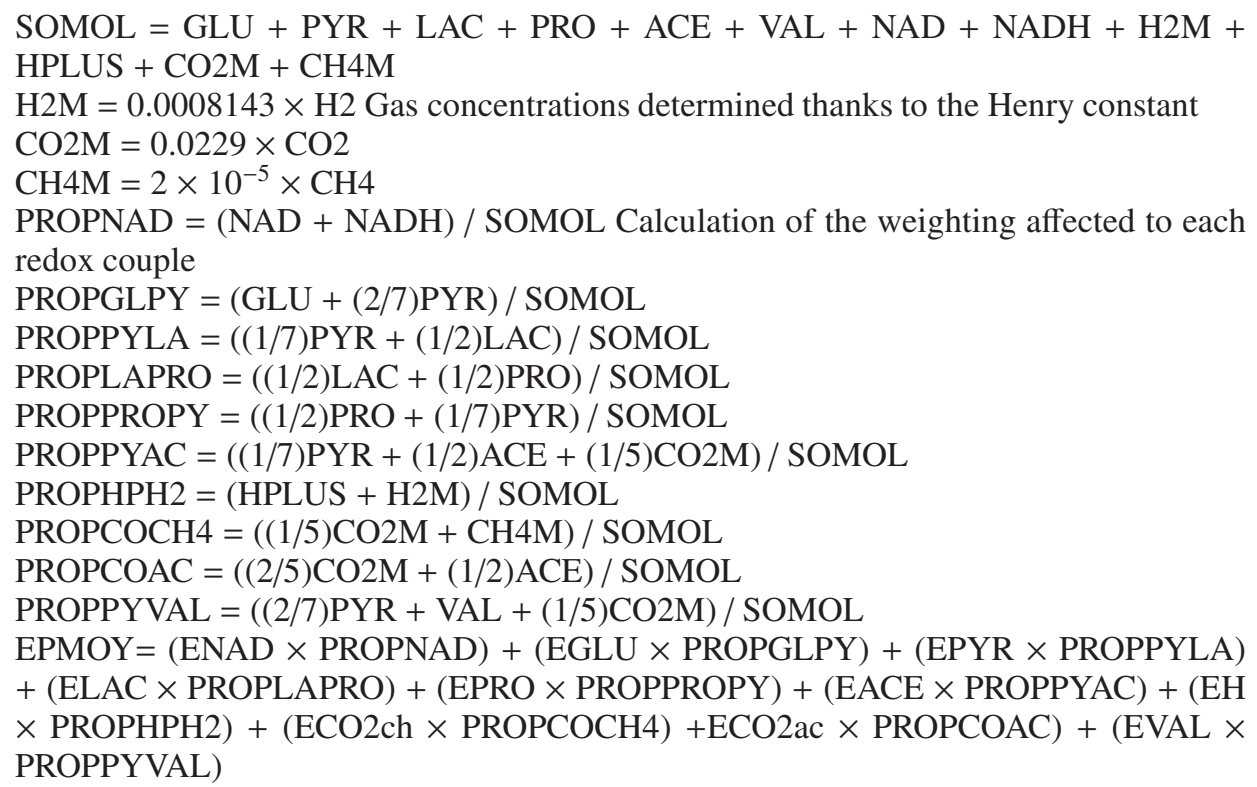

Difference to the average potential

DEGLU $=$ EPMOY - EGLU

DEPYR $=$ EPYR - EPMOY

DELAC $=$ ELAC - EPMOY

DEPRO $=$ EPRO - EPMOY

DEACE $=$ EPMOY - EACE

$\mathrm{DEH}=\mathrm{EH}-\mathrm{EPMOY}$

$\mathrm{DECO} 2 \mathrm{CH}=\mathrm{ECO} 2 \mathrm{CH}-\mathrm{EPMOY}$

$\mathrm{DECO} 2 \mathrm{AC}=\mathrm{ECO} 2 \mathrm{AC}-\mathrm{EPMOY}$

DEVAL $=$ EVAL - EPMOY
Potentials of oxydoreduction reactions

Evr1 = ENAD - EGLU

Evr2 $=$ EPYR - ENAD

Evr3 $=$ ELAC - ENAD

Evr4 $=$ EPRO - ENAD

Evr5 $=$ ENAD - EACE

Evr7 $=$ EVAL - ENAD

Evr8 $=$ ECO2ch - ENAD

Evr9 $=$ ECO2ac - ENAD

Evr10 $=$ EH - ENAD 